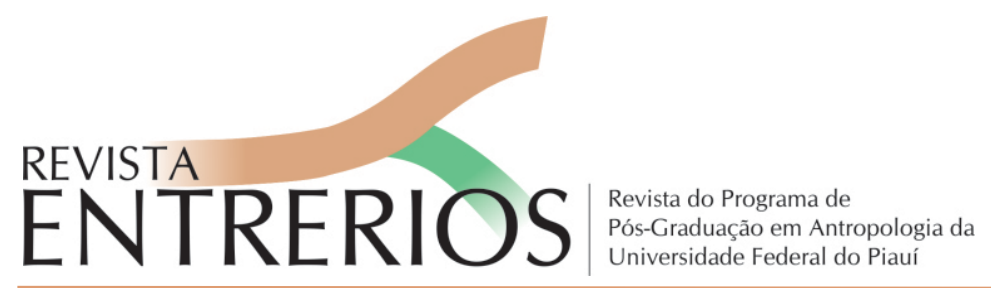

\title{
Diversidade, arbitrários e trânsitos: memorial acadêmico
}

\author{
Fabiano Gontijo \\ Professor Titular - UFPA \\ fgontijo2@hotmail.com
}

\begin{abstract}
Resumo: Trata-se do memorial acadêmico apresentado como requisito para a progressão funcional para Professor Titular da Universidade Federal do Pará (UFPA). O memorial foi defendido publicamente com êxito no dia 4 de dezembro de 2019, diante da banca examinadora composta pelas/os Professoras/es Doutoras/es Rosa Elizabeth Acevedo Marin, (Presidenta), da UFPA, Carlos Alberto Caroso Soares, da Universidade Federal da Bahia (UFBA), Russel Parry Scott, da Universidade Federal de Pernambuco (UFPE), Antônio Carlos Mota de Lima, também da UFPE, Lina Maria Brandão de Aras, da UFBA, e Leila Mourão Miranda, da UFPA. O memorial apresenta as principais atividades de pesquisa, extensão e docência desenvolvidas por mim ao longo das últimas três décadas, com ênfase especial para a atuação junto às Universidades Federais do Piauí e do Pará.
\end{abstract}

Palavras-chaves: Memorial Acadêmico; Professor Titular; UFPA; UFPI.

Abstract: This is the academic memorial presented as an institutional requirement for the progression to Tenured Professor at the Federal University of Pará(UFPA). The memorial was publicly and successfully defended on December 4, 2019, to the examining board composed of Professors/Doctors Rosa Elizabeth Acevedo Marín, (President), UFPA, Carlos Alberto Caroso Soares, Federal University of Bahia (UFBA), Russel Parry Scott, Federal University of Pernambuco (UFPE), Antônio Carlos Mota de Lima, UFPE, Lina Maria Brandão de Aras, UFBA, and Leila Mourão Miranda, UFPA. The memorial presents the main research, social and teaching activities developed by me over the last three decades, with special emphasis on the activities developed in the Federal Universities of Piaui and Pará.

Keywords: Academic Memorial; Tenured Professor; UFPA; UFPI.

1 Doutor em Antropologia, École des Hautes Études en Sciences Sociales, França. Bolsista de Produtividade, Conselho Nacional de Desenvolvimento Científico e Tecnológico, Brasil 


\section{Apresentação}

Esta é uma tarefa árdua: traçar o perfil de sua própria carreira, relatando, com um certo distanciamento e uma dosagem de desinteresse, as experiências profissionais e acadêmicas mais relevantes desenvolvidas ao longo de um determinado período de tempo; ou seja, fazer uma antropologia (e também uma sociologia) do antropólogo - ou uma sócio-antropologia histórica do pesquisador ${ }^{2}$.

A dificuldade encontra-se menos na forma literária do relato do que na necessária objetivação do próprio vivido. Isso não deveria ser problemático, tendo em vista que tradicionalmente, dentre as técnicas de pesquisa etnográfica e sociológica, as entrevistas autobiográficas, as etnobiografias e as reconstituições e recensões de trajetórias e histórias de vida têm ocupado um lugar cada vez maior (BERTAUX, 2005; FEAL, 1990; FISCHER, 2016; GONÇALVES et al, 2012; PASSERON, 1990; PENEFF, 1990). Porém, o objeto dessas técnicas é quase sempre, explicitamente, o "outro", raramente o "mesmo"; ou melhor, raramente "eu mesmo", o próprio utilizador ou aplicador de tais técnicas. Marilyn Strathern, por exemplo, concorda que "[...] os problemas morais assumem uma forma particular quando os antropólogos se voltam para 'sua própria sociedade'. Eles levantam a questão preliminar de como se conhece quando se está em casa" (STRATHERN, 2014, p.133). E quando a "casa" (entre aspas, metafórica, a sociedade e/ou a cultura, objetos tradicionais de estudo) é a própria casa do antropólogo (sem aspas, metonímica, a Universidade a partir da qual a vida acadêmica se desenrola)?

Trata-se pois, aqui, de tentar estabelecer uma antropologia dos meus outros intimos, nos termos de Marc Augé (1994) ${ }^{3}$. Não obstante as críticas e revisões que vêm sendo feitas à maneira de produzir etnografias, respeitantes à inevitável inserção do autor-etnógrafo no seu trabalho e no produto deste, percebe-se ainda o grande desconforto diante da tarefa de elaboração de uma narrativa das experiências sobre a sua própria vida, sobre a sua própria casa (e em sua própria “casa"). Para Cliffrord Geertz (1973) ${ }^{4}$, as experiências são acontecimentos que resultam do jogo entre a causalidade material e a interação social; para Fredrik Barth (2000), seriam o resultado da interpretação desses acontecimentos; enfim, para Joan Scott (1992) ${ }^{5}$, seriam aquilo que constitui os sujeitos enquanto tais, sempre associadas a processos históricos. Quais são, em minha "casa", as minhas experiências em casa, ou seja, os acontecimentos significativos referentes à vida acadêmica que contribuem ou contribuíram para a melhoria da "casa"? Quais são as experiências da alteridade íntima que importam para compor um memorial acadêmico?

2 Dedico esse memorial (e a carreira até aqui) a Maria Helena de Souza Gontijo (19/05/1947-01/10/2015), Wanderlei de Souza Gontijo (16/05/1943-22/11/2018), Régis Moussier (19/01/1948-18/10/2019) e Igor Erick da Silva: gratidão eternal.

3 Para este autor, o objeto de estudo da antropologia são as diversas manifestações da alteridade: o outro exótico, os outros do outro, o outro do interior de nossas próprias sociedades e, enfim, o outro íntimo que se encontra nas diversas manifestações de nossos pertencimentos identitários (AUGÉ, 1994).

4 "[...] the actual living through of events [...]." (GEERTZ, 1973, p.405). Tradução livre do inglês: "[...] a vida real através dos acontecimentos [...]."

5 "It is not individuals who have experience, but subjects who are constituted through experience. Experience in this definition then becomes not the origin of our explanation, not the authoritative (because seen or felt) evidence that grounds what is known, but rather that which we seek to explain, that about which knowledge is produced. To think about experience in this way is to historicize it as well as to historicize the identities it produces." (SCOTT, 1992, p.25-26) Tradução livre do inglês: "Não são os indivíduos que têm experiência, mas sim os sujeitos que são constituídos pela experiência. Experiência nessa definição torna-se, então, não a origem de nossa explanação, não a evidência autorizadora (porque vista ou sentida) que fundamenta o que é conhecido, mas sim aquela que procuramos explicar, aquela sobre a qual o conhecimento é produzido. Pensar na experiência desse modo é historicizá-la, bem como historicizar as identidades que ela produz." 
Passado o reconhecimento dessa dificuldade de objetivação, uma série de outros "problemas" podem ser colocados quando se trata de narrar "os atos e enunciados históricos singulares" (BENSA, 2006) de uma vida profissional, dentre os quais a questão da relevância real de tais fatos ou feitos e não de tais outros na constituição do relato em questão. Assim, o que segue deve ser visto como o resultado de uma seleção mais ou menos consciente, meio arbitrária e, obviamente, não totalmente desinteressada - para fins de progressão funcional ou promoção via defesa pública - de momentos, fatos e atos que, quando colocados uns ao lado dos outros, tendem a fazer sentido e dar-nos a direção coerente de uma vida profissional e de suas assim compostas práticas. Interrogo, pois, a minha trajetória a partir de alguns códigos que organizam minha percepção desorientada dessa trajetória e das práticas que a compõem, sem interrogar-me contudo sobre a natureza desses códigos.

Tentarei, num primeiro momento, descrever o início do meu interesse por ciências sociais em geral e por antropologia em particular, citando o contexto de formação dos descontentamentos que me levaram aos estudos sociais - chamo aqui essa etapa de Flertando com a Ciência Política. Tratarei, em seguida, da profissionalização propriamente dita através da escolarização superior - etapas chamadas de Namorando com a Sociologia e Casando com a Antropologia. Essas três etapas compõem a parte formativa de minha trajetória.

A segunda parte desse memorial é composta pelas atividades desenvolvidas a partir do momento em que me tornei professor adjunto de Antropologia do Departamento de Ciências Sociais (DCS) da Universidade Federal do Piauí (UFPI). Essa parte é denominada performativa, por se tratar de um período em que - acho - aprendi, de fato, a atuar como um profissional das ciências sociais numa instituição federal de ensino superior baseada nos princípios básicos do tripé ensino-pesquisa-extensão (e inovação), com o desempenho de inúmeras atividades típicas do tripé, tais como: aulas na graduação e na pós-graduação (stricto sensu e latu sensu), orientações (de iniciação científica, monitoria, trabalhos de conclusão de curso, mestrado e doutorado), gestão e representação (coordenação de cursos de graduação e de pós-graduação), participação em eventos, publicações, liderança de grupos de pesquisa, realização de pesquisas etc.

Enfim, a terceira parte é dedicada ao momento em que passei a atuar na Universidade Federal do Pará, período relativo a uma série de práticas transformativas por se tratar de uma etapa recente de grande amadurecimento profissional e acadêmico, de mudanças mais ou menos radicais em termos de escolhas teóricas (e metodológicas) para as minhas pesquisas e, finalmente, de tentativa de produção de singularidades temáticas e "experimentações" (mais ou menos no sentido tratado por alguns dos ensaios que compõem o famoso e polêmico Writing Culture).

\section{Período Formativo (até 2002)}

\section{Flertando com a Ciência Política}

Talvez meu interesse por entender o funcionamento dos dispositivos e tecnologias sociais e seus regimes culturais tenha surgido, entre tantas outras razões mais ou menos explícitas, a partir da tomada de conhecimento quase que repentina do descontentamento relativo às múltiplas formas de desigualdades sociais.

Sou originário de uma cidade média do desfavorecido noroeste do estado do Rio de Janeiro, Itaperuna, situada numa zona de produção agropecuária: café, açúcar e gado leiteiro. A elite da cidade, naquele início dos anos 1970 e ainda hoje, se compõe de médicos (elite do jaleco branco), advogados (elite da toga preta) e fazendeiros oportunistas (elite do jeans sujo de terra), muitos deles de origem sírio-libanesa, cristãos e protestantes (presbiterianos e batistas). 
Nasci da união de um membro da elite médica cristã - minha mãe, filha bastarda de um dos donos das mais importantes clínicas da região - e de um membro da elite pecuarista oportunista protestante - meu pai, filho de um fazendeiro mineiro instalado na região. Porém, com a união não desejada pelas respectivas famílias, ambos foram deserdados e o casal teve que começar a vida nova sem apoio das suas famílias originárias. Assim, fui criado numa família restrita - pai, mãe, irmão e irmã -, cuja renda vinha do salário da mãe como professora das redes estadual e municipal de ensino fundamental e do salário do pai como vendedor e frentista de posto de gasolina.

Tive a experiência da possibilidade real da mobilidade social vendo meu pai, um autodidata à moda antiga, tornar-se advogado, com muito esforço e ajuda de uma extensa e forte rede de amizades, e cinco anos mais tarde, depois de prestar concurso público, magistrado. Com a nova ocupação, a família teve de se transferir para uma comarca maior, inicialmente indo viver em Niterói e, em seguida, na Zona Sul da cidade do Rio de Janeiro, em Copacabana. Os dois irmãos mais velhos foram estudando Direito em universidades da rede privada de ensino (Gama Filho e Estácio de Sá), enquanto eu ainda estava cursando o ensino médio em diversos colégios, ora públicos, ora particulares (Pinheiro Guimarães, Princesa Isabel, Sagrado Coração de Maria e Estadual Infante Dom Henriques). Desejando seguir a carreira diplomática ou ser comissário de bordo - puramente por amor aos mapas e desejo de trilhar o planeta -, estudei francês na Aliança Francesa, alemão no Instituto Cultural Brasil-Alemanha (Goethe Institut), japonês no Instituto Cultural Brasil-Japão, inglês no CCAA e, enfim, holandês e espanhol com professores particulares - alguns desses cursos, pagos por colegas dos meus pais ou parentes.

Estes eram anos de imensas transformações a nível nacional: Diretas Já!, redemocratização do País, caos econômico, eleição indireta e morte de Tancredo Neves, o vice José Sarney, Constituinte, eleições livres de 1989... Participando dessa movida brasileira, inicialmente talvez por gosto de multidões, barulho e estardalhaço, fui adquirindo consciência da desigualdade resultante do confronto entre as elites de minha terra natal, mas também daquela, mais urbana, resultante do acirramento da crise econômica e política do período final da ditadura militar e do início da Nova República. A maior inserção das "novas esquerdas" representadas, em particular, pelo Partido dos Trabalhadores nas camadas médias urbanas levou-me ao engajamento político, mesmo sem ainda ter idade legal para votar. Já em 1986, aos 15 anos, estava participando das campanhas políticas para governador do estado, tentando contribuir na eleição do então candidato da coligação PT-PV, Fernando Gabeira, considerado como um ícone da liberdade de expressão àquela altura.

Desde então e até 1990, sem ainda filiar-me a um partido, participei de toda sorte de encontros políticos, campanhas, manifestações, palestras partidárias, comícios e passeatas buscando entender principalmente o porquê da opressão das chamadas minorias - negros, mulheres, homossexuais, portadores de necessidades especiais, umbandistas e candomblecistas, indígenas, favelados, quilombolas... Por um lado, por estar sempre em companhia de pessoas mais velhas, colegas e amigos dos diversos cursos de língua estrangeira em particular de francês -, muitas das quais passaram por algum tipo de sofrimento durante os piores momentos das ditaduras brasileira, portuguesa, espanhola ou argentina, fui levado a interessar-me por uma certa literatura política marxista e leninista de origem soviética (publicadas pelas Edições Progresso) e cubana, mas também por publicações dos movimentos sociais esquerdistas brasileiros (como as revistas da Editora Terceiro Mundo). Por outro lado, fui fortemente influenciado pelos discursos de alguns/mas professores/as do curso secundário, principalmente de história e geografia, a respeito dos problemas econômicos que lhes tocavam tão diretamente.

Foi assim que, pouco a pouco, deixei de lado a ideia de ingressar na carreira diplomática por razões políticas um tanto quanto ingênuas e imaturas - e fui interessando-me cada vez mais por ciência política e sociologia. 
Prestei, então, vestibular na Pontifícia Universidade Católica do Rio de Janeiro (PUC-RJ) em 1989. Fui aprovado e classificado, mas não podia cursar o ensino superior por ainda não ter completado o ensino médio. No ano seguinte, já com o certificado de conclusão do ensino médio, entrei para o curso de Ciências Sociais da Universidade Federal do Rio de Janeiro (UFRJ), com o objetivo de tornar-me cientista político. O Instituto de Filosofia e Ciências Sociais (IFCS) da UFRJ encontrava-se em estado de decomposição material, ao mesmo tempo em que formigavam ideias novas, de inspiração cubana e nicaraguense - estandes de livrarias expunham os últimos lançamentos cubanos no saguão de entrada do prédio e Daniel Ortega, então Presidente da Nicarágua, visitou a Universidade, palestrando na Escola de Comunicação.

\section{Namorando com a Sociologia}

No IFCS/UFRJ, tive acesso não somente ao ensino institucionalizado, mas participei de diversos eventos organizados pela instituição ou por entidades estudantis e outras, além de assistir a defesas de teses de doutorado e dissertações de mestrado em todas as áreas. Até me lembro da visita de Howard S. Becker e, se não me falha a memória, de Jürgen Habermas.

Cursei um único período, o primeiro de Ciências Sociais de 1990 e, apesar do interesse inicial por ciência política e sociologia, talvez eu tenho sido muito menos impressionado pelas aulas do Prof. Francisco Ferraz (ciência política) e dos Profs. Luiz Antônio Machado, Alice Rangel e Bila Sorj (sociologia) do que pelas aulas de antropologia cultural da Profa ${ }^{\text {. Luitgarde }}$ Pereira. Nas aulas desta última fui levado a ler, entre outros, alguns textos que provavelmente ajudaram-me a perceber que a antropologia estava muito mais próxima de meus interesses políticos do que eu pensava: Estruturalismo e Ecologia e Tristes Trópicos, de Claude Lévi-Strauss e a introdução à obra-mestra de Bronislaw Malinowski, Argonautas do Pacífico Ocidental (li o primeiro em espanhol e o segundo e o terceiro, em francês).

Apaixonado por uma pessoa de nacionalidade francesa que havia conhecido fazia três anos àquela altura e descrente nas possibilidades de mudança do Brasil após a eleição presidencial de 1989, que levou ao poder Fernando Collor, terminei o período letivo e pedi o trancamento da matrícula no curso do IFCS/UFRJ para tentar inscrever-me num curso de sociologia na França. Quando cheguei naquele país em 1990, o período de inscrições nas universidades já havia passado e, para não ter que voltar ao Brasil, acabei inscrevendo-me no nível mais avançado do curso livre de "Língua e Civilização Francesas" da Faculdade de Direito e Ciências Econômicas da Université d'Aix-Marseille III (Universidade de Aix-Marselha III), em Aix-en-Provence, na ensolarada e alegre região mediterrânea da França.

O curso do Institut d'Études Françaises pour Étudiants Étrangers (IEFEE, Instituto de Estudos Franceses para Estudantes Estrangeiros), de duração anual, deu-me acesso a noções fundamentais de Direito Civil, Direito Trabalhista, Direitos Humanos e Liberdades, assim como de Literaturas Francesa e Europeia de todas as épocas, Linguística e Fonética, Economia e História Política e Social, dentre outras tantas disciplinas. Dentre essas disciplinas, uma foi-me de grande importância: História Social da Mulher, ministrada pela escritora Paule Constant (com importantes prêmios acadêmicos reconhecidos, como o Prix Goncourt). Um de seus ensaios históricos, Un Monde à l'Usage des Demoiselles (CONSTANT, 1987), talvez tenha sido a primeira obra que li sobre gênero e sexualidade, fazendo o contraponto com os dois volumes de Le Deuxième Sexe, de autoria daquela que havia sido companheira de Paule Constant, Simone de Beauvoir.

Além das aulas do IEFEE, frequentei como ouvinte algumas disciplinas da Faculdade de Letras e Ciências Humanas (Université d'Aix-Marseille I), dentre as quais Sociologia da Mulher, da Prof ${ }^{\text {. }}$ Catherine Flament e Etnologia da Provença, do Prof. Christian Bromberger. 
Participei de aulas magistrais do Prof. Bruno Etienne no Institut d'Etudes Politiques (IEP, Instituto de Estudos Políticos, Aix-en-Provence) sobre a geografia política do mundo árabe norte-africano e assisti a diversos seminários teóricos organizados pela Ecole des Hautes Etudes em Sciences Sociales (EHESS, Escola de Altos Estudos em Ciências Sociais, Marselha). As aulas de Sociologia da Mulher baseavam-se em dados estatísticos oficiais (produzidos pelo Institut National de la Statistique et des Études Économiques, o IBGE francês) sobre a situação da mulher na França, a partir de uma teorização que mesclava referências a Emile Durkheim e a Georg Simmel. As aulas sobre a Provença me mostraram como a perspectiva antropológica pode se adequar ao estudo de sua própria cultura, de sua própria casa, como diria Marilyn Strathern (2014). Bromberger se interessava não só pela sua Provença natal, mas também pela chamada "área cultural" iraniana (curdo-persa) e por manifestações culturais consideradas como marginais pelas ciências institucionalizadas, como o futebol (na França e na Itália), as festas populares contemporâneas, as manifestações de rua etc. Enfim, as aulas de Etienne despertaram-me um forte interesse pelo Norte da África e pelas culturas árabes e berberes, assim como pela questão espinhosa da imigração e aculturação árabes na França.

Em 1991 pude, enfim, inscrever-me no primeiro ano do curso de sociologia na Université d'Aix-Marseille I. Os dois primeiros anos de estudos levaram-me ao "Diploma de Estudos Universitários Gerais" (DEUG, Diplôme d'études universitaires générales), o terceiro ano à "Licenciatura" (Licence) e o quarto ano, ao "Mestrado" (Maîtrise), completando o ciclo de estudos graduados. Em seguida, vieram, depois de um ano de estudos de pós-graduação, o "Diploma de Estudos Aprofundados" (DEA, Diplôme d'études approfondies, equivalente do Mestrado brasileiro) e, enfim, depois de quatro anos, o Doutorado (Doctorat).

As disciplinas obrigatórias dos dois primeiros anos de estudos de graduação em sociologia eram Sociologia Geral, Iniciação aos Métodos da Sociologia, Iniciação às Teorias e Conceitos da Sociologia, Métodos de Medidas Estatísticas Aplicadas às Ciências Sociais, Iniciação aos Métodos da História, Demografia I e Economia I, além de uma língua estrangeira e uma linguagem à escolha optei por aprender o árabe falado na Tunísia e Informática Aplicada às Ciências Sociais -, perfazendo um total de quase 780 horas de aulas durante todo o ano. No segundo ano, as disciplinas obrigatórias eram Sociologia Geral II, Técnicas de Pesquisa (Estatística), Prática de Entrevista e Etnologia/Antropologia I. Optei pelo DEUG deSociologia e Etnologia/ Antropologia e, então, tive que cursar também Etnologia II (Antropologia Biológica) e Iniciação à Análise dos Documentos Etnográficos, além de duas disciplinas optativas a serem escolhidas nos diversos Departamentos do Centro de Ciências Humanas e Letras - optei por História e Civilização dos Mundos Não-Europeus Contemporâneos: América Latina e Oriente Médio e Linguística Aplicada às Ciências Sociais -, perfazendo a mesma carga horária do primeiro ano.

Nesses dois primeiros anos de estudos universitários, as disciplinas que mais atraíram a minha atenção foram as de antropologia, em particular a de Iniciação à Análise dos Documentos Etnográficos, baseada na utilização da imagem na produção de dados etnográficos (dos filmes de Jean Rouch até a internet). Nas disciplinas Técnicas de Pesquisa e Prática de Entrevista, os/as estudantes foram levados à confecção de uma pesquisa, "em tamanho real”, sobre os modos de vida estudantis nos diversos campi da Université d'Aix-Marseille; a pesquisa, quantitativa (mais de 2.000 questionários foram passados) e qualitativa (cada estudante realizava cerca de cinco entrevistas semiabertas), foi orientada pelos Profs. R. Establet e R. Baudelot, eminentes especialistas em Sociologia da Educação, publicada posteriormente em forma de livro.

No terceiro ano de graduação, as disciplinas obrigatórias eram poucas (Sociologia III, Métodos Quantitativos Aplicados às Ciências Sociais e Observação das Formas Simbólicas - Métodos Qualitativos), deixando aos/às estudantes um leque de possibilidades de disciplinas optativas tanto nas áreas de sociologia e antropologia, quanto nas áreas dos demais departamentos do Centro. A escolha das optativas já era dirigida pelo interesse futuro do/a estudante na monografia a ser realizada no ano seguinte. 
Em cada uma das disciplinas optativas, uma série de trabalhos mais ou menos importantes era exigida, muitas vezes orientados diretamente por pesquisadores/as dos diversos laboratórios da Universidade.

Cursei, então, Sociologia do Desenvolvimento e do Terceiro Mundo e produzi, para esta disciplina, um trabalho monográfico sobre a construção da imagem do Brasil através de artigos publicados durante um ano no jornal cotidiano Le Monde (Indignation, Indigne Nation: le Brésil à travers le journal Le Monde, 1993/1994, 19p.). Para a disciplina Sociologia Urbana, realizei, conjuntamente com um colega senegalês, uma mini-monografia sobre os processos de favelização das metrópoles brasileiras e senegalesas (Urbanisation au Tiers-Monde: Sénégal et Brésil, 1993/1994, 46p.). No curso de Sociologia do Meio-Ambiente, escrevi um trabalho sobre a experiência da revista brasileira Ecologia \& Desenvolvimento (Ecologia \& Desenvolvimento: un magazine, un pays, un contexte, 1993/1994, 91p.). Para os cursos obrigatórios também produzi trabalhos de certa importância, como um sobre o "mercado da morte", numa perspectiva comparada entre o Brasil, a Tunísia e a França, para o curso sobre metodologia qualitativa (Le Marché de la Mort: sémiologie des cimetières - Brésil, Tunisie et France) e, para a disciplina Sociologia III, um na área de Sociologia do Trabalho, das Organizações e das Profissões (Aix-en-Provence: une ville, un restaurant, un contexte, 50p.), sobre o campo da alimentação numa cidade média provençal, a cidade onde eu residia. Outras disciplinas foram cursadas nesse terceiro ano, como Sociologia da Comunicação e dos Mass-Media, Sociologia da Educação, Geografia Humana e Antropologia Urbana.

No quarto e último ano de graduação, só era necessário cursar uma disciplina obrigatória - Sociologia IV -, os/as estudantes devendo dedicar-se quase que exclusivamente aos seminários organizados por seus/suas respectivos/as orientadores/as de monografia de conclusão de curso. Muito interessado por sociologia e antropologia do corpo, realizei, para o Trabalho de Conclusão de Curso / Monografia de final de graduação, uma pesquisa etnográfica / sociográfica junto a um grupo de frequentadores/as de um trecho da praia de Copacabana autoreconhecidos/as/es como homossexuais, gays, travestis, transexuais, garotos/as de programa, lésbicas, dentre outras formas de pertencimento, e a influência da AIDS em suas vidas (práticas sexuais, aparências corporais, identidades), sob a orientação da Prof ${ }^{\text {a }}$ Michèle Pagès-Delon. $\mathrm{O}$ trabalho se transformou em livro, publicado em 1998 sob o título Corps, Apparences et Pratiques Sexuelles: socio-anthropologie des homosexualités sur une plage de Rio de Janeiro (Corpos, Aparências e Práticas Sexuais: socio-antropologia das homossexualidades numa praia do Rio de Janeiro), minha primeira publicação (GONTIJO, 1998) ${ }^{6}$.

Durante os quatro anos da graduação, participei do movimento de representação estudantil e fui eleito e reeleito representante oficial das turmas de graduação em sociologia e etnologia/antropologia e representante oficial dos alunos do Centro de Ciências Humanas e Letras junto ao Conselho Universitário.

\section{Casando coma Antropologia}

A partir daí, minhas indagações começaram a ser as seguintes pelos próximos seis ou sete anos, ao longo dos estudos pós-graduados e da primeira inserção profissional: quais as relações entre as (homo)sexualidades, as situações rituais carnavalescas e a epidemia de HIV/AIDS? Como podem ser estudados os processos formadores do binarismo de gênero e suas (re)formulações enquanto fenômenos socioculturais em momentos e situações rituais? Como podem ser estudadas as vivências das (homo)sexualidades em relação à questão das construções sociais do gênero? Homossexualidades, "terceiro sexo"? Ou homossexualidades, bricolage cultural a partir dos papéis e identidades de gênero masculino e feminino?

6 O diploma obtido na graduação foi revalidado no Brasil em junho de 2001 pelo Instituto de Filosofia e Ciências Sociais da UFRJ como equivalente ao de "Bacharel em Ciências Sociais". 
A partir dessas (re)construções sociais do gênero, quais as formulações identitárias possíveis no caso das homossexualidades e das homosocialidades, em particular no Brasil contemporâneo? Como acontecem essas formulações em diferentes situações carnavalescas no contexto urbano da cidade do Rio de Janeiro? Qual a influência da AIDS nessas formulações identitárias homossexuais e homosociais? Enfim, que relação pode existir entre esse conjunto ritual representado pelo carnaval do Rio de Janeiro, as formulações identitárias homossexuais baseadas no gênero e as consequências sociais e culturais da epidemia de HIV da forma como vinha se expandindo pelo Brasil? Alguns dos termos usados nesses questionamentos, eu não ousaria usar mais nos dias de hoje, em razão de revisões teóricas que fui levado a fazer ao longo dos períodos performativo e transformativo, como será visto mais adiante.

Mas, por que abordar cientificamente tais temáticas? Talvez por experiências decorrentes do processo pessoal de socialização - as chamadas razões pessoais ou imponderáveis da minha própria vida cotidiana -, talvez por casualidades ligadas às instituições de ensino e às linhas de pesquisa aí desenvolvidas, talvez pela conjugação das duas razões. Depois da graduação na Université d'Aix-Marseille I, mandei um projeto de Mestrado e Doutorado para a Ecole des Hautes Etudes em Sciences Sociales (EHESS), filial de Marseille, sobre "identidades de gênero homossexuais extremizadas", tratando de travestis/transexuais versus go-go boys/barbies (aqueles sujeitos hiper-viris que povoavam as praias e as boates cariocas). A proposta foi aceita, mas acabei modificando a temática, adaptando-a ao tema do carnaval que já era tratando por aquele que viria a ser meu orientador pelos próximos anos, Prof. Michel Agier (EHESS-Institut de Recherche pour le Développement).

Em minha monografia de conclusão de curso de graduação em sociologia, assim como na dissertação de mestrado e na tese de doutorado em antropologia social e cultural (ambas defendidas na EHESS), tentei responder às perguntas citadas acima, com o objetivo final de caracterizar a diversidade das maneiras de ser e existir homossexuais no Brasil e, em particular, na cidade do Rio de Janeiro. Em sociedades ocidentais complexas, como a brasileira, que se inserem no que Marc Augé (1994) chama de "supermodernidade" (surmodernité, cujas características principais são as transformações nas relações entre o tempo e o espaço, a individualização das referências culturais e a predominância dos meios de comunicação de massa), sociedades que vivem a complexa dialética local-global, torna-se difícil falar de somente uma identidade masculina ou de uma identidade feminina, e mais ainda de uma identidade homossexual única - e até mesmo de homossexualidade. Qualquer observação da realidade nos leva a falar de identidades relativas e de identificações múltiplas e plurais.

Assim, o sujeito homossexual não seria mais simplesmente aquele que adotaria um papel de gênero feminino e que se comportaria, então, segundo os padrões socioculturais da feminilidade em vigor, nem tampouco aquele que se identificaria unicamente com os padrões da masculinidade (FRY, 1982); ao contrário, alguns sujeitos homossexuais parecem ter-se tornado pessoas que se afirmam homens que mantêm relações sexuais (também) com homens e que, às vezes, reúnem um certo número de traços e de elementos socioculturais oriundos inicialmente de um papel de gênero ou de outro, mas também de uma série de outras referências (como, por exemplo, o universo sócio-profissional ou o universo do lazer) em torno de uma identificação, ou do que preferi chamar de imagem identitária, que regula uma parte de seu comportamento e o guia em suas práticas sociais. Essa reunião de traços parece provir do encontro/confronto com o mesmo por um lado - aquele que também mantém relações sexuais com pessoas do que consideram e é considerado como sendo o mesmo sexo biológico - e, por outro, com o outro aquele que mantém relações sexuais com pessoas do que consideram e é considerado como sendo o sexo biológico diferente do seu próprio. A AIDS e suas consequências sociais e culturais pareciam tornar ainda mais complexas as formulações identitárias homossexuais. 
Portanto, dentro de uma mesma sociedade, a cultura sexual seria frequentemente composta e recomposta por vários sistemas de referências, o que levaria à diversidade de maneiras de concepção de gênero e das identidades nele baseadas. Isso era o que eu pensava àquela altura, nos termos que se usava naquele momento.

Na monografia de conclusão de graduação, meu interesse voltou-se para as práticas corporais e sexuais de um certo número de homens (e algumas poucas mulheres) que mantinham relações sexuais exclusivamente ou preferencialmente com homens e que frequentavam uma parte da praia de Copacabana por eles denominada de Bolsa e transformada assim em uma espécie de território gay - infelizmente, eu ainda desconhecia o trabalho de Néstor Perlongher. A praia parecia tornar-se quase uma espécie de região moral, no sentido atribuído por sociólogos da Escola de Chicago, já que os grupos mais formalizados ou institucionalizados de frequentadores elaboravam ali tradições, mitos de origem e ritos de passagem para solidificar a sua razão de estar-lá (percebe-se aqui uma nítida influência, àquela altura, de Michel Maffesoli). Então, os indivíduos construíam interativamente identidades múltiplas e redes sociais ao se encontrarem com os outros "diferentes" deles. A praia seria um daqueles lugares identitários que Marc Augé (1994) opõe aos não-lugares que se desenvolveriam e estariam se expandindo na contemporaneidade. A praia tornava-se um lugar de diferenciações socioculturais diversas, de identidades-alteridades relativas, apesar da heterogeneidade das aparências corporais. Copacabana, assim como Ipanema, Barra, Flamengo e todas as outras praias do litoral carioca, estavam divididas informalmente em uma série de "postos" e "points", cada um com a sua representação sociológica singular e com a sua importância na divulgação de elementos referenciais para a formulação das aparências identitárias ou... imagens identitárias.

Também constatei que os frequentadores da Bolsa apresentavam características comuns muito diferentes das de outros espaços de sociabilidade reconhecidos como gays, como na praia adjacente de Ipanema, no território denominado Farme (por se encontrar em frente à rua Farme de Amoedo). Concebi que a praia, para essas pessoas, representava mais do que um simples lugar de encontro e lazer, era também - e sobretudo - um lugar de formulação e negociação identitárias: em Copacabana, essa formulação baseava-se na heterogeneidade do "mundo gay" travestis, mariconas, prostitutos/michês, pessoas em fase de transsexualização, homossexuais viris, mulheres minoritárias etc. eram todos/as/es "aceitos/as/es" e estavam mesclados/as/es neste espaço comum -, ao passo que em Ipanema a formulação se dava em torno da aparente homogeneidade viril do "mundo gay" - somente eram "aceitos" neste espaço as pessoas híperviris e masculinas. Essa diferença pareceu-me, num primeiro momento, estar vinculada às diferenças de origem social e de classe dos frequentadores de cada uma dessas duas praias; mas, essa explicação se mostrando insuficiente, preferi recorrer à história da ocupação de cada um desses territórios e às trajetórias biográficas dos frequentadores, o que me permitiu afirmar que as mudanças sociais dos últimos trinta anos (desde a década de 60) e as consequências sociais da AIDS teriam, de fato, determinado essas duas concepções diferentes de imagens identitárias homossexuais territorializadas em pontos distintos das praias cariocas.

A partir daí, observei as reações dos frequentadores da Bolsa ao risco representado pela AIDS. Percebi que a Bolsa parecia ajudar a estruturar essas reações: se sentindo pouco tocados pelas campanhas demasiado globais e distantes de luta contra a epidemia lançadas pelos governos local e nacional, era frequentando a Bolsa que as pessoas entrevistadas tomavam consciência dos riscos e das mudanças de comportamento e de práticas necessárias para o combate a esses riscos. O estudo levou-me, por um lado, a observar que as reações à AIDS não eram somente determinadas pelas "categorias sociais" ou "sócio-profissionais" às quais pertenciam os interlocutores, mas também pelo grau de coesão dos frequentadores, pelo simples fato de frequentar um lugar identitário em comum e compartilhar as ideias ambientes; por isso mesmo, tinha-se que as reações eram bastante homogêneas, apesar da diversidade de imagens identitárias presente neste território. Por outro lado, este trabalho levou-me a cunhar a noção de 
imagem identitária, baseada nas aparências corporais socialmente construídas.

Na dissertação de Mestrado (D.E.A., Diplome d'Études Approfondies) em Ciências Sociais (Sociologia-História-Antropologia) $)^{7}$, apresentada e defendida em 1996 na EHESS-Marseille, busquei caracterizar duas imagens identitárias homossexuais cariocas e a maneira como eram construídas, estruturadas e formuladas socialmente a partir da extremização do binarismo de gênero: as travestis, extremo da feminilidade, e os gays híper-viris (chamados então de barbies), extremo da masculinidade. Partindo-se da ideia de que os momentos e situações rituais eram dispositivos com a finalidade simbólica de criar e reforçar as identidades relativas através de alteridades mediadoras, colocando em relação o mesmo e o outro e colocando em relação uns e a coletividade num só conjunto, considerei essas situações rituais como ocasiões privilegiadas para a observação de identidades baseadas no binarismo de gênero e numa espécie de continuum estando a serem reformulados. O carnaval do Rio de Janeiro, enquanto conjunto de situações ritualizadas inseridas no contexto espacial urbano singular do Rio de Janeiro e no contexto temporal do "ciclo festivo do verão", mostrou-se ser o quadro ideal para a observação dessas formulações identitárias. Limitei-me à observação da participação de certos sujeitos às festividades carnavalescas (baile Scala Gala Gay da casa de espetáculos Scala e baile gay da Gafieira Elite Clube; bandas Carmen Miranda e de Ipanema; ensaios e desfiles de escolas de samba) e das possibilidades que essas festividades ou situações sociais (MITCHELL, 1987) poderiam oferecer para a construção de suas imagens identitárias.

O carnaval é frequentemente visto como um rito de inversão que opera principalmente a inversão do sistema sexo/gênero (RUBIN, 1975) e da hierarquia social (ORTIZ, 1976; Da MATTA, 1978; PEREIRA DE QUEIROZ, 1992) - ou melhor, mais do que a inversão, percebi que o carnaval operava a conversão, a perversão, a transversão, a reversão e todas as possibilidades de versões. No Rio de Janeiro, onde o carnaval deve ser estudado como uma espécie de reinvenção de tradição, o carnaval parecia funcionar, para os/as interlocutores/as, principalmente como um conjunto de situações permissivas a partir das quais esses sujeitos acabavam por integrar-se ao todo social e à coletividade, podendo reivindicar, a partir de então, sua cidadania plena, ainda que isso durasse para alguns o tempo efêmero de um carnaval.

A temática tratada no mestrado foi aprofundada na tese de doutorado em antropologia social, defendida em 2000, também pela EHESS-Marseille ${ }^{8}$, numa tentativa de dar conta das transformações, mudanças e metamorfoses observadas nas construções de gênero e na cultura sexual brasileira em geral e nas experiências (homo)sexuais cariocas em particular, notadamente desde o aparecimento da AIDS. Inicialmente, a tese deveria tomar a forma de uma etnografia das festividades carnavalescas do Rio de Janeiro, do aspecto altamente sexualizado dessas festividades em geral e da apropriação da maior parte dessas festividades por sujeitos que se auto-reconheciam como homossexuais em particular. Essa descrição deveria levar à compreensão da maneira como os ritos carnavalescos cariocas serviam realmente de locus social para a reformulação de identidades calcadas na sexualidade. Assim, durante o carnaval, podiase perceber uma maior participação de sujeitos homossexuais nas festividades, inclusive através da divulgação do carnaval feita pela imprensa, o que acabava deixando uma sensação de "abertura" e de aceitação das diferenças muito maior do que no resto do ano; ou seja, havia uma sensação de permissividade em relação às experiências homossexuais.

A ênfase dada à dimensão histórica das formulações identitárias homossexuais através do carnaval fez-me perceber a existência de dois períodos bastante distintos, não só em relação à elaboração das imagens identitárias, mas também em relação à própria recriação recente de uma espécie de cultura sexual brasileira: parecia haver, na história recente da cultura sexual brasileira,

7 O diploma foi revalidado no Brasil em abril de 2001 pelo Programa de Pós-Graduação em Sociologia e Antropologia (PPGSA) do IFCS/UFRJ como equivalente ao de "Mestre em Sociologia".

8 O diploma foi revalidado no Brasil em julho de 2001 pelo Programa de Pós-Graduação em Antropologia Social do Museu Nacional/UFRJ como equivalente ao de “Doutor em Antropologia Social”. 
uma fase anterior à epidemia de AIDS e uma fase ainda em constituição, posterior às primeiras consequências sociais e culturais da epidemia. Assim, a AIDS aparecia em minhas pesquisas não como uma doença (ou um fato biológico), mas principalmente como um contexto social, motor de importantes transformações nas concepções das imagens e aparências ligadas às formulações de gênero e às experiências da sexualidade.

A partir da escolha de uma série de situações sociais do carnaval carioca, observei a maneira como as mais diversas pessoas participantes viviam esses momentos rituais, construindo localmente (e, às vezes, provisoriamente) suas imagens identitárias sexualizadas. Entrevistando um grande número de carnavalescos/as e empregados/as diversos/as do universo das escolas de samba, organizadores/as de bailes e eventos carnavalescos semiprivados, idealizadores/as de bandas e blocos, assim como frequentadores/as dessas situações sociais, pude chegar a uma caracterização geral do carnaval (gay e não gay) carioca. Parecia que as consequências sociais e culturais da AIDS (dentre as quais encontrava-se a exacerbação do culto ao corpo e à saúde física) induziu a geração de imagens identitárias cada vez mais efêmeras e sempre em reformulação, o que acabou levando a um novo tipo de carnaval com festividades frequentadas por pessoas que já não valorizavam as antigas formas identitárias de gênero limitadas pela oposição entre masculino e feminino, mas criavam um leque flexível de possibilidades relativas ou relacionais de auto-definição, em torno, por exemplo, do termo "G.L.S." (gays, lésbicas e simpatizantes) ou do termo "geração saúde". A “cultura G.L.S." (da qual faziam parte imagens identitárias como os gays híper-viris da Zona Sul do Rio de Janeiro, mas também as drag queens) se compunha de elementos provenientes de diversos sistemas de referências, em contra-referência às identidades fixas do sistema hierárquico de gênero (FRY, 1982; FRY; MacRAE, 1983) e propondo uma "fragmentação" identitária baseada na supervalorização das aparências e das imagens de si.

Assim, algumas bandas eram frequentadas essencialmente por pessoas que veiculavam imagens ligadas à "cultura G.L.S.", como a Banda Carmen Miranda ou a Banda Simpatia É Quase Amor; alguns bailes eram frequentados por um público quase exclusivamente composto de membros da "cultura G.L.S.", como os bailes rave parties (por exemplo, X-Demente e B.I.T.C.H.), onde já não se escutava samba, mas músicas eletrônicas (e-music) como em qualquer discoteca ou club europeu ou norte-americano; alguns ensaios de escola de samba à moda antiga eram frequentados por travestis, homens que se consideravam efeminados e homossexuais masculinos que não se identificavam com o modelo de aparência proposto pela "cultura G.L.S.", enquanto outras escolas de samba do "novo tipo" eram frequentadas quase que exclusivamente por pessoas que seguiam o modelo "G.L.S." Percebia-se, sobretudo, que estes dois tipos de carnaval se opunham não somente como dois tipos distintos de concepção das festividades carnavalescas, mas como duas gerações ou dois contextos sociais diversos: a "era Milton Cunha" se opunha à "era Joãosinho Trinta", como o sistema hierárquico de gênero (FRY, 1982; FRY; MacRAE, 1983; MENDES-LEITE, 1993; PARKER, 1991), os homossexuais efeminados e os entendidos se opunham às drag queens e aos adeptos da "cultura G.L.S." Enfim, as festividades carnavalescas acabavam servindo de espaço de expressão de todas as imagens identitárias homossexuais, consolidando, pouco a pouco, uma maior aceitação das experiências da diversidade sexual e de gênero na sociedade carioca como um todo, apesar da estigmatização imposta pelos primeiros anos da epidemia de AIDS.

Durante o último ano de doutoramento, já sem a bolsa, voltei ao Brasil para redigir a tese e tive a minha primeira experiência profissional na docência em uma pequena instituição de ensino superior do interior do estado do Rio de Janeiro (Fundação São José - Faculdade de Filosofia de Itaperuna), como professor de sociologia para o primeiro período do curso de Licenciatura em Ciências Sociais. Essa primeira experiência foi de grande importância, principalmente em se tratando de um curso de ciências sociais no interior do Brasil, cujos discentes eram, em sua grande maioria, professores/as negros/as do ensino fundamental em busca de aperfeiçoamento. 
A tese foi realizada, a partir do segundo ano, no âmbito de um acordo de cotutela entre a EHESS e a UFRJ. Sendo assim, a defesa, em dezembro de 2000, ocorrida em Paris, contou com a presença, além do orientador francês, Michel Agier, e de um membro da instituição francesa, o então presidente da EHESS, Marc Augé, de dois membros representando a instituição brasileira, quais sejam, a co-orientadora, Yvonne Maggie, e Peter Fry, ambos do IFCS/UFRJ. A tese obteve menção "Très honorable, avec félicitations du jury" e foi parcialmente traduzida e publicada como livro no Rio de Janeiro, em 2009, pela Editora Garamond, sob o título O Rei Momo e o Arco-Íris: Carnaval e Homosexualidade no Rio de Janeiro (GONTIJO, 2009). Arranjos de capítulos da tese foram publicados, um como capítulo de livro (GONTIJO, 2005c) e outros dois, como artigos (GONTIJO, 2004b, 2008a).

Aconselhado pelos Profs. Peter Fry e Yvonne Maggie, encaminhei ao Conselho Nacional do Desenvolvimento Científico e Tecnológico (CNPq) um pedido de Bolsa de Recém-Doutor, Programa Especial de Estímulo à Fixação de Doutores (PROFIX) para desenvolver um projeto de pesquisa no IFCS/UFRJ. Enquanto o pedido tramitava pela instituição de apoio à pesquisa, trabalhei, também como docente, nas Faculdades de Guarapari, no Espírito Santo, ministrando aulas de sociologia para o curso de Ciências Contábeis e de antropologia cultural para o curso de Turismo. Fiz concurso para Professor Substituto de Sociologia na Universidade Federal do Espírito Santo, sendo aprovado em primeiro lugar, mas com a implementação da bolsa solicitada ao CNPq, optei pelo IFCS/UFRJ.

Vale lembrar, antes de prosseguir, que durante todo o período da Graduação e da PósGraduação, tomei gosto maior ainda pelas viagens. Reproduzo aqui um trecho publicado em um artigo de minha autoria (GONTIJO, 2017b, p.271):

Qual não foi minha surpresa, no final da década de 1980, ao me deparar, na primeira leitura que eu fazia do então já clássico Tristes Tropiques, de Claude Lévi-Strauss, com a seguinte passagem que abre o livro: "Odeio as viagens e os exploradores. E eis que me preparo para contar minhas expedições." (Lévi-Strauss, 1955, p. 9) ${ }^{9}$. Que Lévi-Strauss odiasse os "explorateurs", ok. Mas... as voyages?! E eu ali, naquele momento, iniciando minhas leituras em antropologia para saber se era aquele realmente o campo disciplinar mais adequado para minha formação profissional... Eu desejava trabalhar em alguma área que me permitisse percorrer o mundo (logo, ser comissário de bordo?) refletindo sobre as relações entre os povos (logo, ser diplomata?). Eis que alguém me disse que o antropólogo era aquele intelectual que refletia sobre a diversidade cultural a partir de suas experiências de contato com diferentes povos - mas, não só isso. Ou seja, a antropologia era o caminho para a realização do meu sonho profissional: estudar viajando ou viajar estudando. Que bom que logo percebi que Lévi-Strauss estava sendo irônico ao dizer que odiava as viagens, num livro todo dedicado a suas viagens!

Era isso mesmo que eu queria - viajar e estudar -, embora Lévi-Strauss alertasse para os "ossos do ofício". Acabei viajando para estudar. Realizando minha formação superior na França, eu me especializei no estudo da diversidade sexual e de gênero num contexto brasileiro (mais especificamente, carioca). De volta ao Brasil, continuei me interessando pela diversidade sexual e de gênero, mas agora na região Nordeste, num primeiro momento e, em seguida, na região Norte, regiões onde residi e resido: viajei para trabalhar. Enquanto isso, fui me tornando um "viajante profissional", um turista para além de antropólogo: trabalhei para viajar.

Contrariando o "je hais les voyages" e desejando contatos com modos de vida diferentes dos meus, "exóticos", aproveitei de certas facilidades da vida na Europa e, visitei quase todos os países do continente, o norte da África, o Oriente Médio e, mais longe, o Caribe, os Estados Unidos, uma pequena parte do sul da África e da Ásia e também quase todos os estados do Brasil.

9 Tradução do francês: "Je hais les voyages et les explorateurs. Et voici que je m'apprête à raconter mes expéditions." 
O gosto pelas viagens acabou motivando ainda a participação em alguns congressos e encontros científicos ao longo do tempo passado na França, como o V Congresso Luso-AfroBrasileiro de Ciências Sociais de 1998, em Maputo, Moçambique, o IX Congresso da Sociedade Brasileira de Sociologia de 1999, em Porto Alegre, o VII Congresso Internacional de Estudantes de Antropologia de 1999, em Miranda do Douro, Portugal, mas também o VII Festival Question de Genres de 1997, em Lille, França, o I Seminário Homosexualités de 1997 no Centro Georges Pompidou, em Paris, França, o Seminário anual de Antropologia da Saúde de 1995, em Marselha, França, o Seminário Sexualidades Brasileiras e AIDS de 1994, no Rio de Janeiro... Em quase todos esses eventos, apresentei textos.

No projeto para a obtenção da Bolsa de PROFIX, propus uma pesquisa etnográfica sobre o que designei como uma "estética homossexual" que poderia estar na base do carnaval carioca. Os trabalhos científicos e ensaios sobre o carnaval carioca abundavam, mas nenhum (ou poucos) citavam a importância dos sujeitos que se auto-reconheciam como homossexuais na caracterização das festividades (ENEIDA, 1958; JÓRIO; ARAÚJO, 1969; GOLDWASSER, 1975; ORTIZ, 1976; LEOPOLDI, 1978; Da MATTA, 1978; PEREIRA DE QUEIROZ, 1992; CAVALCANTI, 1994; VALENÇA, 1996), gerando um fenômeno de "não-dito" talvez consequente de um certo mal-estar acadêmico.

A "era dos carnavalescos", cujo maior expoente era Joãosinho Trinta, representava a introdução da estética (ou habitus?) das classes médias nos desfiles e em particular, a de homossexuais brancos das áreas mais abastadas da cidade, não somente nos desfiles, mas principalmente nos bastidores das escolas de samba, criando e divulgando uma espécie de "estética homossexual" no carnaval. Essa estética extrapolaria os limites das escolas de samba e os mesmos carnavalescos, figurinistas e artistas plásticos estariam se ocupando da decoração de bailes e locais de eventos carnavalescos, divulgando ainda mais suas expressões artísticas, ou seja, suas estéticas.

Os carnavalescos talvez fossem personagens centrais na produção e na divulgação dessas estéticas, mas os principais personagens seriam aqueles que produziam materialmente as idealizações dos carnavalescos, como os figurinistas, estilistas, costureiros, desenhistas, decoradores, aderecistas, escultores, ferreiros, vidraceiros, trabalhadores dos barracões das escolas de samba em geral por um lado e, por outro, os diretores de alas que mandavam fazer e comercializavam as fantasias e os presidentes de escolas que coordenavam a totalidade do trabalho e propiciavam emprego para cada um desses personagens. O público que assistia aos desfiles (realmente ou virtualmente) e os desfilantes consumiam essa produção artística, aprovando-a (ou reprovando-a) e ajudando a divulgá-la, acrescentando ativamente elementos. Enfim, a difusão e a assimilação das obras oriundas dessas estéticas pareciam ir muito além do curto momento do carnaval e poderiam estar ajudando na integração e na aceitação paulatina de uma grande parte das imagens identitárias homossexuais, também durante o ano todo em momentos não rituais.

Tratava-se de estudar as formas materiais - ou cultura material - que tomavam, então, as diversas "estéticas homossexuais" no carnaval carioca, como se constituíam e se divulgavam. Ou seja, abordar a produção artística, como se inseria no mercado artístico brasileiro e carioca, mas também no mercado particular do carnaval, formando seu próprio campo, com seus agentes e com seus capitais (cultural, social, econômico e simbólico) específicos (BOURDIEU, 1979).

Além da pesquisa que foi realizada com o apoio da bolsa, o Departamento de Antropologia Cultural da UFRJ propôs que eu ministrasse duas disciplinas do curso de graduação em ciências sociais. A integração ao Departamento foi bastante rápida, talvez devido à afinidade entre as temáticas abordadas em minhas pesquisas e aquelas tratadas por alguns/mas professores/aspesquisadores/as do Departamento, sendo logo convidado pela Prof ${ }^{\text {. }}$ Mirian Goldenberg para participar de cursos de extensão no Fórum de Ciência e Cultura (Corpos, sexualidades e conjugali- 
dades na cultura brasileira em outubro/novembro de 2001 e A cultura do corpo: gênero e desvio na sociedade brasileira em março/abril de 2002) e para publicar um capítulo em um livro organizado por ela (Nu E Vestido), a minha primeira publicação em português (GONTIJO, 2002), além de ser convidado também pelas Profas. Yvonne Maggie e Mônica Grin (esta última do Departamento de História), para participar da sessão temática sobre Diferenças e Desigualdades Sociais na reunião anual da ANPOCS de 2001 e, pelos Profs. Olívia Cunha e Flávio Gomes (do Departamento de História), para participar do seminário História e Antropologia realizado no IFCS/UFRJ em junho de 2002.

A bolsa previa a integração do jovem pesquisador durante os doze meses de vigência, mas a principal proposta desse tipo de bolsa era a da absorção total do pesquisador pelo Departamento, quando da abertura de concurso público para o provimento de vaga para Professor Adjunto. As negociações para o fim da longa greve do ensino superior público de 2001 levaram o Governo Federal a propor a realização de concursos públicos nos primeiros meses de 2002. Foi assim que, tomando conhecimento dos editais dos concursos, fiz as provas e fui aprovado em primeiro lugar como Professor Adjunto de Antropologia na Universidade Federal do Piauí (UFPI). Uma nova etapa começava em minha vida, agora em Teresina, a calorosa y... caliente capital piauiense.

\section{Experiências Performativas (2002-2013)}

Além do concurso para a vaga de Professor Adjunto de Antropologia na Universidade Federal do Piauí (UFPI), eu me inscrevi em mais outros quase vinte concursos em Universidades Federais nas áreas de antropologia, sociologia e metodologia das ciências sociais. As primeiras provas aconteceram na UFPI. Ao ser aprovado ali, desisti de todos os outros concursos e me dediquei à preparação da mudança para Teresina. O concurso aconteceu em março de 2002 e em maio do mesmo ano iniciei minhas atividades lotado no Departamento de Ciências Sociais (DCS).

A área de Antropologia do DCS/UFPI encontrava-se em um estado de letargia quando da minha contratação: escassez de professores, praticamente nenhuma pesquisa, baixo nível de interesse por parte dos/as estudantes, nenhum projeto de extensão, infraestrutura precária sem previsão de melhorias... O Centro de Ciências Humanas e Letras (CCHL) também se encontrava em crise. A crise era o resultado da ausência de políticas voltadas para o ensino superior federal durante os dois mandatos do governo do Presidente Fernando Henrique Cardoso. Com a contratação de novos/as professores/as doutores/as, após a longuíssima greve de 2001, e a volta de muitos/as professores/as do quadro docente da UFPI que se encontravam afastados/as para o doutoramento, uma nova dinâmica foi-se instaurando rapidamente no CCHL, tendo consequências bastante benéficas para a necessária reestruturação do curso de ciências sociais e a criação de uma política de pós-graduação, praticamente inexistente até aquela altura na UFPI.

Mas, a verdadeira mudança ocorreria ao longo do primeiro mandato do Presidente Luís Inácio Lula da Silva, em particular nas Universidades Federais situadas nas regiões Nordeste e Norte, ainda antes do Programa de Reestruturação das instituições federais de ensino superior (REUNI). Com as verbas federais e estaduais (o Piauí elegeu e reelegeu um governador do Partido dos Trabalhadores), apareciam projetos novos, pesquisas criativas, propostas engajadas com a mudança social, um ambiente de ebulição de ideias... A UFPI se beneficiou dessa situação e ao longo da década de 2000 e início da seguinte, um gigantesco salto de qualidade foi dado, o que refletiu obviamente na minha atuação, já que era o momento em que eu, pela primeira vez, estava performando, de fato, como docente, pesquisador, gestor e extensionista no âmbito de uma Universidade Federal. 
Vale lembrar um fato que, para muitos, teve um valor simbólico enorme, mas para quem vivia no Piauí, teve um valor efetivo ainda maior: pelo fato de o Piauí ser, no início da década de 2000, o estado mais empobrecido do Brasil, o Presidente Lula escolheu iniciar o seu primeiro mandato em Teresina, levando todo o seu ministério para a capital piauiense para, durante alguns dias, (de)mo(n)strar que seu compromisso de campanha com as camadas menos favorecidas da população brasileira estava se cumprindo. Eu acompanhei, durante esses dias, toda a comitiva em suas atividades pela cidade, um momento de grande emoção, em razão da situação de abandono na qual se encontrava o estado e a maneira como a esperança e a vontade de transformação pareciam estar se instalando a partir dali.

Foi aprovado, ainda em 2002, o início do funcionamento do curso de mestrado em Políticas Públicas na UFPI. Em seguida, foram aprovados também os cursos de mestrado em Letras e em História do Brasil. Fui imediatamente integrado ao corpo docente e ao colegiado do Programa de Pós-Graduação em Políticas Públicas e participei da montagem do projeto do Programa de Pós-Graduação em Letras. Algum tempo depois, fui integrado, como colaborador, ao Programa de Pós-Graduação em História do Brasil, embora a minha participação nas atividades desse curso tenha sido menor do que nos outros. Enfim, ministrei disciplinas no curso de mestrado em Ciências da Saúde em duas ocasiões, sem no entanto manter vínculo com o curso. No final da década de 2000, foi aprovado o curso de mestrado em Antropologia e Arqueologia, do qual fui coordenador por duas gestões. Nesse momento, deixei os Programas de Letras e de História do Brasil para dedicar-me com mais vigor ao novo Programa e continuei no Programa de Políticas Públicas, agora com um curso de Doutorado. Paralelamente, colaborei junto ao Programa de Pós-Graduação em Ciências Sociais da Universidade Federal do Maranhão por um certo intervalo de tempo, atuando em conjunto com a Prof ${ }^{\text {a }}$ Sandra Nascimento.

No Programa de Políticas Públicas, ministrei sistematicamente, durante todos os anos até 2011, a disciplina Cultura e Identidade, obrigatória para a linha de pesquisa de mesmo nome, fazendo a relação entre antropologia, ética em pesquisa e políticas públicas. Nesse Programa, orientei e coorientei sete dissertações e iniciei a orientação de uma tese, assim que se iniciou o curso de Doutorado, já na década de 2010, mas não terminei a orientação em razão de minha mudança para o Pará. Geysa E. Sá, economista e professora, a minha primeira orientanda a defender uma dissertação, desenvolveu um trabalho pioneiro sobre a relação entre o mercado e as culturas homossexuais em Teresina (SÁ \& GONTIJO, 2006), enquanto Arnaldo E. da Silva, o meu primeiro co-orientando, realizou um belo trabalho etnográfico sobre os mecanismos de constituição das práticas violentas em bairros periféricos da capital piauiense (SILVA \& GONTIJO, 2006).

No Programa de Letras, co-ministrei a disciplina Gênero, Sexualidades e Culturas Identitárias Sexuais e ministrei a disciplina Tópicos em História e Sociedade: A Formação da Identidade Nacional Brasileira e a Questão Racial, ambas optativas da linha de pesquisa de Linguística, da qual fiz parte, e orientei um único trabalho de dissertação, de autoria de Edilce Madeiro de Lima, sobre a construção das representações da sexualidade e da raça em O Bom-Crioulo, de Adolfo Caminha. Liderei um grupo de pesquisas, intitulado Identidades Culturais e Sexualidades, juntamente com o Prof. Sebastião Lopes, da área de Letras. No Programa de História, orientei uma dissertação sobre o apagamento social das mulheres artistas plásticas piauienses e uma outra sobre o carnaval de São Luís do Maranhão. Esses três Programas de Pós-Graduação tinham a particularidade de unir discentes e docentes oriundos/as de horizontes diversos, o que criava, de fato, a própria necessidade de realização de trabalhos interdisciplinares, rompendo com as barreiras institucionais que tanto bloqueavam nossa criatividade de pesquisadores/as (a tal “imaginação sociológica” de Wright Mills). 
Além desses Programas de Pós-Graduação, participei de algumas especializações ou pósgraduações latu sensu, cabendo destaque para cinco delas: uma em Políticas Públicas, uma em Afrodescendência e Educação, uma em História do Brasil, uma em Cultura Visual e Metodologia do Ensino (Arte e Patrimônio) e enfim, a última, em Seguraça Pública (Políticas Públicas e Gestão de Segurança Pública). Na primeira, não ministrei disciplinas, apenas orientei um trabalho monográfico. Na segunda, ministrei a disciplina de Afrodescendência e Educação e orientei um trabalho monográfico. Na especialização em História do Brasil, ministrei duas disciplinas e orientei alguns trabalhos monográficos. Na especialização em Cultura Visual, ministrei disciplina e orientei trabalho monográfico. A especialização em Segurança Pública foi criada a partir de uma demanda do Ministério da Justiça com o objetivo de fornecer formação continuada a policiais e gestores de órgãos de segurança pública em geral. Ministrei, para as três primeiras turmas do curso (de 2005 a 2008), a primeira disciplina de cada turma, voltada para a sensibilização dos/ as estudantes em relação à diversidade social e cultural (Identidade e Diferença e Cultura, Sociedade, Poder e Diversidade se intitulavam as disciplinas).

Em 2003, fui convidado para ministrar uma disciplina no curso de extensão do Programa Terceira Idade em Ação (PTIA), intitulada Retratos Reais: A Realidade Brasileira através do Cinema. Foi uma experiência ímpar, a primeira na extensão universitária. Depois, participei de duas edições de um curso de extensão em Antropologia da Imagem, organizado pelo Programa de Pós-Graduação em Antropologia e Arqueologia, que seria criado no final da década, e ainda de diversos outros cursos de extensão, a convite de colegas da UFPI, como o Projeto Cajuína Sociológica. Confesso que tive poucas iniciativas, de minha autoria, relacionadas à extensão, pelo fato talvez de acreditar que as atividades de pesquisa e de ensino, assim como a organização de eventos diversos, devem ou podem envolver pessoas não matriculadas na instituição, sendo abertas para a participação de todos/as.

Ao longo dos onze anos passados na UFPI (2002-2013), integrei um grande número de comissões (colegiados de cursos, organização de eventos, criação de núcleos de pesquisa, montagem de cursos de graduação, elaboração de projetos de cursos de pós-graduação, etc.) e bancas de concursos para docente (na UFPI, na UESPI, na UFMA e em outras instituições de ensino e pesquisa) e de processos seletivos de pós-graduação. Cabe destacar algumas comissões. Em 2005, participei da comissão de elaboração do curso de mestrado em Ciências Sociais, mas infelizmente não conseguimos enviar a proposta de curso novo para a Coordenação de Aperfeiçoamento de Pessoal do Ensino Superior (CAPES). Participei da comissão de elaboração do curso de graduação em Arqueologia, aprovado em 2008 com recursos do REUNI. Com os recursos, foi construído um prédio para abrigar o curso, diversos laboratórios e um museu. Fui o primeiro vice-coordenador do curso durante as duas primeiras gestões. Mais adiante detalharei a minha experiência com a arqueologia.

Enfim, em 2007, fiz parte de uma comissão para a elaboração de uma proposta de curso de mestrado em Antropologia, um curso que funcionaria na modalidade de associação de instituições de ensino superior, prevista pela CAPES, com o curso existente na Universidade Estadual de Campinas. Em razão das dificuldades para a obtenção da documentação necessária a tempo, a proposta acabou sendo enviada para a CAPES em associação com o Programa de PósGraduação em Sociologia e Antropologia do IFCS/UFRJ. O curso não foi aprovado, mas o desafio estava colocado. No ano seguinte, após uma espécie de força-tarefa para a elaboração de uma proposta viável que representasse de forma mais adequada o Piauí, foi aprovado o funcionamento do curso de mestrado em Antropologia e Arqueologia da UFPI, sob a minha coordenação. Voltaremos às importantes atividades desempenhadas junto a esse Programa mais adiante. Além de comissões, participei, ao longo dos anos passados no Piauí, de um número bastante elevado de bancas examinadoras de qualificação de mestrado e de doutorado e de defesas de dissertação de mestrado e, em menor quantidade, de teses de doutorado - no total, entre 2002 e 2013, foram 48 bancas de defesa e 26 bancas de exames de qualificação em diversas 
instituições, tais como UFPI, Universidade Federal do Rio de Janeiro (PPGSA/IFCS e PPGAS/Museu Nacional), Universidade Federal Fluminense, Universidade Federal do Maranhão, Universidade Estadual de Feira de Santana, Universidade Federal da Bahia, Universidade Federal do Ceará, dentre outras.

Na graduação, ao longo das décadas de 2000 e início da seguinte, ministrei disciplinas para os mais diversos cursos. Para o curso de Ciências Sociais, ministrei todas as disciplinas obrigatórias de Antropologia (Teorias Antropológicas I, II e III e Tópicos Especiais de diversas temáticas, por exemplo), além das disciplinas introdutórias de antropologia ou sociologia para outros cursos, tais como Geografia, Comunicação, Odontologia, Enfermagem, Medicina, Farmácia, Nutrição, Arquitetura, etc, além do curso de Arqueologia.

Quanto às atividades de pesquisa, sempre acreditei que a docência e a pesquisa deveriam estar intimamente ligadas, sendo que uma não poderia existir sem a outra. Assim, desde que cheguei na UFPI, convidei, no primeiro mês de atuação, em maio de 2002, duas estudantes do curso de Serviço Social para me ajudar no desenvolvimento de um projeto de pesquisa sobre as consequências da AIDS (ou "cultura da AIDS", como chamamos àquela altura) em Teresina no âmbito do Programa de Iniciação Científica (PIBIC - CNPq/UFPI). Conversando com alguns professores do Departamento, percebi, por um lado, que em Teresina ainda não havia pesquisas sobre as consequências sociais e culturais da epidemia de HIV/AIDS. Por outro lado, os indicadores estatísticos produzidos pela Coordenação Estadual de DST / AIDS e pelo Ministério da Saúde apontavam para um duplo processo de feminilização e juvenilização da epidemia no Piauí. Diante desses fatos, realizei essa pesquisa com o intuito de mapear a experiência da AIDS em Teresina, remontar a história da gestão pública da epidemia no estado e tentar compreender as particularidades da tal "cultura da AIDS" no município. Uma dissertação de mestrado orientada por mim no Programa de Pós-Graduação em Políticas Públicas ampliaria ainda mais essa pesquisa dois anos depois.

Em maio de 2003, foi iniciado um novo projeto de pesquisa no âmbito do PIBIC (CNPq/UFPI). As mesmas duas estudantes do curso de Serviço Social me ajudaram, desta vez, na realização de uma pesquisa sobre as "culturas homossexuais" teresinenses. Em maio de 2002, eu havia ajudado a fundar a primeira organização não-governamental teresinense de cidadania homossexual, o Grupo Matizes, juntamente com pessoas oriundas dos mais diversos horizontes (professores/as universitários/as, militares, estudantes, prostitutos/as, políticos/as, etc). Ajudei a elaborar o estatuto da ONG. O Grupo conseguiu organizar, em junho de 2002, com apoio da Coordenação Estadual de DST / AIDS, a I Parada do Orgulho Gay de Teresina, levando às ruas da cidade mais de 2.000 pessoas, o que causou certo impacto e repercussão na mídia local. Hoje em dia, as Paradas da Diversidade, como são chamadas agora, atraem uma multidão somada em uma centena de milhares de pessoas.

Com a vitória do Partido dos Trabalhadores nas eleições para o Governo Estadual em 2002, foi atendida uma das principais reivindicações do Grupo Matizes: a criação da Coordenadoria Estadual de Livre Orientação Sexual (CELOS). Juntamente com a Coordenação do Grupo Matizes, ajudei na preparação do estatuto da nova coordenadoria, que começou a funcionar no início de 2003, sob a liderança de uma importante sindicalista da área da saúde na cidade, Maria Ayres - a CELOS seria transformada, quatro anos depois, em Centro de Referência Homossexual "Raymundo Pereira", em homenagem ao cantor piauiense que fundou uma das mais antigas associações de cidadania homossexual do Brasil, o Grupo Atobá do Rio de Janeiro. Porém, assim como o Grupo Matizes, a Coordenadoria não dispunha de dados fiáveis e informações suficientes para elaborar seus projetos e programas sociais que objetivavam o combate ao preconceito e à discriminação contra pessoas homossexuais e a conscientização da população estadual sobre a necessidade do respeito à diversidade sexual e de gênero. 
Visando à produção de informações que pudessem servir ao Grupo Matizes e à CELOS, iniciei uma pesquisa sobre as culturas identitárias homossexuais teresinenses e a discriminação por orientação sexual em maio de 2003 (projeto intitulado Identidades Culturais e Culturas Identitárias Homossexuais Teresinenses). Em maio de 2004, ainda no âmbito do programa de iniciação científica (CNPq/UFPI), iniciei uma nova pesquisa, desta vez sobre as experiências de mulheres teresinenses que se auto-reconheciam como lésbicas, com um estudante do curso de Ciências Sociais e uma de minhas orientandas do Programa de Pós-Graduação em Políticas Públicas (projeto intitulado Culturas Identitárias Homossexuais Teresinenses: Trajetórias e Memórias de Mulheres que Amam Mulheres). Minhas pesquisas despertaram o interesse dos pesquisadores do Centro Latino-Americano em Sexualidade e Direitos Humanos (CLAM), do Instituto de Medicina Social (IMS) da Universidade do Estado do Rio de Janeiro (UERJ), coordenado por Sérgio Carrara e Maria Luiza Heilborn, que passaram a me convidar para inúmeros eventos e publicações a partir de 2003, dando maior projeção ao que se produzia no Piauí e às realidades regionais (GONTIJO, 2004c). Essa parceria com o CLAM/UERJ permitiu a minha inserção numa importante rede de pesquisas (com a participação em eventos, colaboração em pesquisas nacionais, alimentação de bases de dados, etc.), com destaque para as atividades que eu viria a desenvolver, a partir daí, com Anna Paula Uziel (UERJ) e, principalmente, Laura Moutinho (então UERJ, atualmente USP), dentre outras/os pesquisadoras/es. Voltaremos a essas atividades mais adiante.

As pesquisas com temáticas sobre a diversidade sexual e de gênero continuaram ao longo dos anos seguintes, sempre envolvendo discentes da graduação com a concessão de Bolsas de Iniciação Científica e discentes da Pós-Graduação, voltadas, entre 2005 e 2012, para a caracterização e a compreensão dos relacionamentos afetivos e dos arranjos conjugais e parentais de sujeitos que se auto-reconheciam como homossexuais em Teresina, num primeiro momento e em seguida, em São Luís, no Maranhão. A partir de 2007, essas pesquisas passaram a contar com uma Bolsa de Produtividade em Pesquisa do CNPq e geraram uma série e publicações (GONTIJO, 2005b; GONTIJO, 2007; GONTIJO, SOUSA; EVANGELISTA, 2008; GONTIJO, REIS, SOUSA; COSTA, 2017).

Abre-se aqui um parêntese importante: embora hoje em dia eu perceba algumas limitações de termos e expressões que eu empregava livremente ao longo da década de 2000, tais como "culturas homossexuais", "culturas identitárias homossexuais", "homossexualidades" e "identidades culturais", esses eram os instrumentos analíticos de que eu dispunha, naquele momento, para definir os sujeitos e/ou objetos das pesquisas que eu estava realizando, sempre com o objetivo de cartografar (produzir informações históricas sobre os espaços-tempos das experiências sexuais), sociografar (elaborar dados sociológicos sobre os grupos, coletivos, populações, comunidades) e etnografar (descrever as situações sociais e suas práticas), ou seja, de mapear a configuração das experiências da diversidade sexual e de gênero naqueles contextos tão particulares que pareciam ser Teresina, no Piauí, e São Luís, no Maranhão, e por extensão, a partir da década de 2010, o interior desses dois estados. Feche-se o parêntese.

A partir dessas primeiras pesquisas desenvolvidas, foram organizados eventos e atividades de divulgação - como as Semanas anuais da Diversidade Sexual a partir de 2003, realizadas na UFPI em parceria com o Grupo Matizes e com a CELOS; e palestras e seminários em escolas públicas e órgãos do Governo, em parceria com as Secretarias Estaduais de Educação e do Trabalho e Emprego, dentre outras - e encontros e reuniões com representantes dos mais diversos órgãos do Governo e parlamentares locais, com o objetivo de viabilizar a implementação de políticas públicas voltadas para o fortalecimento da "cidadania homossexual" - uma lei estadual e uma lei municipal que penalizam a discriminação por orientação sexual foram aprovadas e sancionadas; uma lei municipal sobre direitos previdenciários para companheiros / as de sujeitos homossexuais foi sancionada; o programa 
Brasil Sem Homofobia foi implantando no estado; foi criado o Disque Cidadania Homossexual; foi instalada uma delegacia especial para "as minorias"; cursos curtos de formação para policiais e agentes de segurança foram montados; o direito à visita íntima para casais de homossexuais foi regulamentado nos presídios estaduais; etc. Todas essas atividades eram monitoradas de perto ou propostas e organizadas por colegas docentes, juntamente com os/as demais membros das entidades e dos órgãos envolvidos.

Na segunda metade da década de 2000, uma outra frente de pesquisa foi por mim aberta, além da primeira sobre a diversidade sexual e de gênero. Em 2005, quando um discente egresso da graduação em Ciências Sociais da UFPI foi aprovado para desenvolver uma pesquisa junto ao Instituto do Patrimônio Histórico e Artístico Nacional (IPHAN), na Superintendência do Piauí, fui convidado para orientá-lo. Tratava-se do Programa de Especialização em Patrimônio (PEP), uma cooperação da Organização das Nações Unidas para a Educação, a Ciência e a Cultura (UNESCO) com o IPHAN - especialização transformada alguns anos depois, já sem o apoio da UNESCO, em Mestrado Profissional em Patrimônio Cultural. O trabalho fazia parte dos esforços do IPHAN, de um lado, para registrar a arte santeira piauiense - ou seja, os saberes e fazeres de escultores de peças sacras -, e de outro, para viabilizar o tombamento de seus locais de exposição, em particular uma igreja católica da capital (GONTIJO; SILVA, 2010). Paralelamente a esse novo interesse pelo patrimônio e suas políticas - principalmente nesse momento em que o IPHAN estava passando por uma grande transformação, com uma série de inventários de cultura imaterial sendo realizados por todo o Brasil -, passei a me dedicar também aos registros visuais (em particular, fotografias) no âmbito da pesquisa antropológica.

Em 2006, cadastrei dois grupos de pesquisa junto ao CNPq: Sexualidades, Corpo e Gênero (SEXGEN) e Antropologia, Imagem e Patrimônio (GAIP), ambos atualmente vinculados à Universidade Federal do Pará (UFPA). Nesses grupos, passei a congregar estudantes de graduação e pós-graduação e pesquisadores/as de diversas instituições. Os interesses pelas temáticas do patrimônio e da imagem se juntaram, a partir de 2006, com o meu envolvimento com a arqueologia.

Descobri o próprio estado do Piauí e, em particular, o sertão semiárido. Deparei-me com o belo trabalho que vinha sendo desenvolvido há algumas décadas na Fundação Museu do Homem Americano (FUMDHAM) pela equipe das arqueólogas Niède Guidon, Anne-Marie Pessis (UFPE) e Conceição Lages (UFPI) na região dos Parques Nacionais da Serra da Capivara e da Serra das Confusões, dentre outros locais, como o Parque Nacional de Sete Cidades. O Festival Interartes, organizado pela FUNDHAM com o apoio do Governo do estado e da Fundação Itaú Cultural, realizado no Parque Nacional da Serra da Capivara em três edições (2003, 2004 e 2005), levou-me a elaborar um pequeno trabalho sobre a relação entre arte, arqueologia e a construção da cidadania naquelas regiões empobrecidas (GONTIJO, 2008b). As leituras na área de arqueologia se tornaram rapidamente um de meus hobbys prediletos, principalmente quando comecei a conhecer arqueólogos/as de outros estados que desenvolviam estudos no campo da arqueologia pública ou arqueologia contemporânea destaque para a Prof ${ }^{a}$ Márcia Bezerra, com a qual fiz amizade em 2006 num pré-evento da Reunião Brasileira de Antropologia, realizado em Goiás. As Profas. Conceição Lage, do Núcleo de Antropologia Pré-Histórica, e Claudete Dias, do Programa de História, ambas da UFPI, convidaram-me para integrar o projeto de elaboração de um curso pioneiro de graduação em Arqueologia na UFPI, que começou a funcionar em 2008 sob a minha vice-coordenação.

Com isso, desenvolvi entre 2007 e 2010, paralelamente aos projetos sobre arranjos conjugais e parentais homossexuais em Teresina e São Luís, um projeto de pesquisa intitulado Patrimônio, Arqueologia e Sexualidades: catalogação e interpretação das técnicas corporais sexuais na arte rupestre do Parque Nacional da Serra da Capivara. O tema dos grafismos rupestres do Piauí exercia (e ainda exerce) sobre mim um fascínio extremo, com suas representações tão diversificadas, muitas delas podendo ser associadas a práticas sexuais, inclusive, possivelmente, entre pessoas 
aparentemente de genitálias similares - muito mais tarde, já no Pará, eu teria acesso a leituras que enrobusteceriam as minhas possibilidades de intepretação sobre as práticas sexuais através de registros materiais pré-coloniais, gerando publicações (GONTIJO; SCHAAN, 2017; FERNANDES; GONTIJO, 2019). Embora essa pesquisa no Piauí tenha gerado baixa produção algumas orientações e trabalhos apresentados em eventos -, em razão das dificuldades técnicas encontradas para levar adiante a pesquisa, esse foi o ponto de partida para a solidificação do meu envolvimento com a arqueologia, a ponto de juntar forças para propor a criação do curso de mestrado em Antropologia e Arqueologia, iniciado em 2009 sob a minha coordenação.

Para que se compreenda melhor a situação da antropologia no Piauí, no momento em que cheguei, e sua relação com a arqueologia, cabe reproduzir aqui um trecho de síntese de um artigo que publiquei em 2015, precisamente sobre a formação da antropologia e a história das pesquisas de interesse antropológico no estado (GONTIJO, 2015a, p.60):

Em síntese, parece que as preocupações antropológicas diletantes, no Piauí, eram supridas por pensadores sociais e historiadores até a ancoragem da arqueologia no estado com os grandiosos projetos empreendidos por Niède Guidon e sua equipe no final da década de 1970 e início da década de 1980. Um dos membros da equipe, Vilma Chiara, funda a antropologia "científica", de inspiração estruturalista, na UFPI, no início da década de 1980. Porém, em pouco tempo, ao longo da década de 1980 e, sobretudo, 1990, os dois campos disciplinares parecem ter divergido fazendo com que não se perceba sequer que um dia possam ter caminhado juntos - vale lembrar que as perspectivas epistemológicas adotadas tinham dificuldade em conjugar antropologia e arqueologia, sobretudo com as preocupações da arqueologia da equipe de Niède Guidon contradizendo as novas preocupações interpretativistas da antropologia de Vilma Chiara.

Enfim, se na década de 1990 e início de 2000, a formação e, por conseguinte, a pesquisa em antropologia pareciam moribundas, a partir de meados da década de 2000, com o início da renovação do quadro docente da UFPI e a criação do curso de graduação em arqueologia, há uma nova aproximação dos campos que desemboca na formação do Programa de Pós-Graduação em Antropologia e Arqueologia, de inspiração levemente boasiana e, em seguida, a criação do Programa de Pós-Graduação em Arqueologia, fortemente marcado pela formação em ciências naturais por parte de seus docentes. A esse primeiro retrato da formação do campo da antropologia no Piauí deve ser acrescido um outro itinérario relativo às pesquisas que vêm sendo realizadas no estado na última década - exorto, portanto, os pesquisadores locais para que deem continuidade a esse mapeamento.

Para apresentar as atividades desenvolvidas na virada das décadas de 2000 para 2010 e uma espécie de guinada que parece se dar nesse momento, com a criação do Programa de PósGraduação em Antropologia e Arqueologia da UFPI, é preciso, antes, expor um pouco longa e detalhadamente alguns "movimentos" de grande relevância para a consolidação da minha trajetória nesse período performativo: a participação em eventos e a criação e/ou inserção de/em redes de pesquisas sobre a diversidade sexual e de gênero. Esses "movimentos" não são lineares no tempo, nem hierarquizados; ao contrário, estão entrelaçados. Esses "movimentos" ajudarão a compreender, mais adiante, algumas importantes mudanças em meus interesses de pesquisa, principalmente quando passo a atuar no novo Programa de Pós-Graduação em Antropologia e Arqueologia da UFPI e, mais tarde, no Programa de Pós-Graduação em Antropologia da UFPA.

\section{Primeiro Movimento: o CLAM}

Ao longo da década de 2000, o CLAM/IMS/UERJ, já citado acima, desempenhou um papel seminal na agregação de pesquisadores/as, no incremento da produção e no financiamento de pesquisas no campo das sexualidades no Brasil e, particularmente, no Nordeste, um pouco menos no Norte. 
O CLAM realizou eventos de grande alcance, muito ousados, com recursos fartos, além de promover pesquisas durante as Paradas de Lésbicas, Gays, Bissexuais e Transexuais/Transgêneros (LGBT) das regiões Nordeste e Norte sobre os "modos de vida" e "comportamentos" de pessoas homossexuais e sobre a discriminação por orientação sexual. Os eventos e atividades do CLAM geraram publicações, inclusive através de uma coleção especialmente criada para a divulgação das pesquisas realizadas pelos/as parceiros/as, coleção Sexualidade, Gênero e Sociedade da Editora Garamond (na qual foi publicado um livro de minha autoria - GONTIJO, 2009). Atualmente, o CLAM publica pela Editora da UERJ, não mais pela Garamond, além de abrigar duas ou três revistas e/ou boletins.

Em 2003, o CLAM realizou um seminário em Recife intitulado Novas Legalidades e Democratização da Vida Social: família, sexualidade e aborto, reunindo juristas, médicos, agentes dos movimentos sociais e, claro, muitos/as antropólogos/as e cientistas sociais; o livro resultante desse seminário foi publicado pela Garamond em 2005 com um pequeno artigo de minha autoria (ÁVILA, PORTELLA; FERREIRA, 2005; GONTIJO, 2005a). Confesso que esse seminário foi especialmente importante para dar visibilidade as minhas pesquisas junto aos colegas do eixo Sul-Sudeste. Grande parte dos/as pesquisadores/as mais atuantes nos dias de hoje no campo dos estudos sobre sexualidades participou, de alguma forma, de atividades promovidas pelo CLAM ou trabalhou diretamente no CLAM - simpósios, fóruns, mesas redondas e grupos de trabalho em diversos eventos, como Congressos da ANPOCS, Reuniões Brasileiras de Antropologia, Congressos da Sociedade Brasileira de Sociologia e outros, foram promovidos, organizados ou apoiados pelo CLAM.

As parcerias com as Profas. Anna Paula Uziel e Laura Moutinho, firmadas nesse momento, foram de fundamental importância para a minha produção: a primeira foi responsável pela publicação de parte de minha tese em forma de livro, como já citei acima, e coautora de um capítulo de livro, além de parceira em eventos (UZIEL; GONTIJO, 2006); a segunda se tornou uma parceira fiel na coordenação de atividades em eventos e no desenvolvimento de uma série de ações ao longo da década de 2000 e no início da seguinte.

\section{Segundo Movimento: a ABIA}

A Associação Brasileira Interdisciplinar de Aids (ABIA), sediada no Rio de Janeiro, já havia sido, ao longo das décadas de 1990 e início de 2000, uma grande promotora de pesquisas no campo dos estudos sobre sexualidades e importante agregadora de pesquisadores/as, uma relevante parcela deles/as, antropólogos/as. Um evento realizado pela ABIA (talvez um dos últimos) em 2003 no Rio de Janeiro, intitulado Homossexualidade: produção cultural, cidadania e saúde, foi de suma importância para pesquisadores/as que, como eu, haviam sido recémcontratados no Nordeste, para a divulgação de suas pesquisas conduzidas em contextos fora do eixo Sul-Sudeste. O evento gerou o livro com o mesmo título, publicado em 2004 pela própria ABIA, contendo um capítulo de minha autoria (RIOS et al, 2004; GONTIJO, 2004). O seminário, de acordo com o espírito que era próprio da ABIA, agregou psicólogos/as, historiadores/as, sociólogos/as, médicos/as, juristas, ativistas/militantes, agentes das diversas esferas do poder público, além de antropólogos/as, todos/as provenientes dos quatro cantos do Brasil e de países da América Latina. Talvez o CLAM tenha se inspirado na ABIA, já que algumas pessoas do primeiro vieram do segundo e o primeiro, de certa forma, tomou na década de 2000 o lugar do pioneirismo que havia sido ocupado pelo segundo na década de 1990. A ABIA era uma organização não-governamental, o CLAM é um núcleo de pesquisa vinculado a uma instituição pública de ensino, pesquisa e extensão. 


\section{Terceiro Movimento: o CISO, a REA/ABANNE e a REDOR}

Em relação às regiões Nordeste e Norte, tenho a impressão de que os Encontros de Ciências Sociais do Norte e Nordeste (CISO) e as Reuniões de Antropólog@s do Norte e Nordeste / Reuniões Equatoriais de Antropologia (ABANNE/REA) foram espaços importantes para os estudos sobre as sexualidades nessas regiões, assim como os Encontros da Rede Feminista Norte e Nordeste de Estudos e Pesquisas sobre Mulher e Relações de Gênero (REDOR) haviam sido o espaço seminal para os estudos de gênero.

O último CISO aconteceu em 2012 no Piauí, a última REA/ABANNE, em 2015 em Alagoas e a última REDOR, em 2018 na Bahia. A REA/ABANNE será retomada em 2019, a REDOR está em pleno vigor e o futuro do CISO é incerto. O CISO acontecia a cada dois anos, em anos ímpares (com irregularidades), enquanto a REA/ ABANNE acontecia também a cada dois anos ímpares. A REDOR, por sua vez, parece que acontecia anualmente, mas tem acontecido também a cada dois anos pares nas últimas edições.

No CISO, acho que os/as antropólogos/as sempre foram a maioria e, de certa forma, acabavam por pautar os temas, determinando a relevância das temáticas mais inovadoras, originais, criativas e, com certeza, mais diretamente ligadas às demandas sociais do momento em questão. Na REDOR, a situação era mais variada, predominando as pesquisadoras das áreas de educação, serviço social, sociologia e história.

Fui a uma única edição da REDOR, realizada em 2008 em Belém, onde, pela primeira vez, homens participaram de uma mesa-redonda para discutir homossexualidade. Foi bastante polêmico. Eu compartilhei a mesa com Jorge Lyra (Instituto PAPAI/PE) e Cristina Donza Cancela (UFPA), a anfitriã.

Esses três eventos começaram as suas atividades entre a segunda metade das décadas de 1980 e a primeira de 1990: o CISO começou em 1987 (não tenho certeza), a ABANNE (que passou a ser também REA em 2007), em 1989 (não tenho certeza) e a REDOR foi criada em 1992. Tenho quase certeza de que os grupos de trabalho que coordenei com Laura Moutinho (e em uma única ocasião com Berenice Bento) e os minicursos que ministrei em diversas edições do CISO e da REA/ ABANNE, a partir de 2003, foram os primeiros espaços de discussões sistematizadas sobre sexualidades em eventos de ciências sociais nas duas regiões. Antes dessas atividades nesses eventos, não encontrei nada nos meus arquivos.

\section{Quarto Movimento: Desfazendo Gênero, Enlaçando Sexualidades e Congressos da ABEH}

Já no final das décadas de 2000 e início de 2010, surgiram eventos mais temáticos que tiveram e ainda têm grande relevância na produção de estudos sobre sexualidades na área de ciências sociais e, em particular, em antropologia, nas duas regiões. Penso particularmente nos eventos bianuais tais como o Seminário Internacional Enlaçando Sexualidades (a primeira edição foi em 2009, sempre realizado na Bahia) e o Seminário Internacional Desfazendo Gênero (a primeira edição foi em 2013, inicialmente realizado no Rio Grande do Norte, depois na Paraíba e em 2019 em Pernambuco). Participei de edições desses eventos com a coordenação de grupos de trabalho, em conjunto com Fátima Lima, da UERJ (e uma vez com Flávia Teixeira, da Universidade Federal de Uberlândia).

Também na década de 2010, algumas edições do Congresso Internacional de Estudos sobre a Diversidade Sexual e de Gênero da Associação Brasileira de Estudos de Homocultura (chamados inicialmente de Congressos da $\mathrm{ABEH}$ ) foram realizadas na região Nordeste (nenhuma edição foi realizada no Norte), embora a ABEH exista desde o início da década de 2000 (GONTIJO, 2004d). Apesar de a ABEH ser mais voltada para os estudos culturais, muitos/as antropólogos/as e sociólogos/as, sobretudo estudantes de graduação e pós-graduação, vêm participando do evento e, em grande medida, aproveitando-se desse espaço para testar metodo- 
-logias e teorias inovadoras, o que não ocorre tão facilmente em eventos mais disciplinares (e disciplinados), como as Reuniões Brasileiras de Antropologia, os CISO e as REA/ ABANNE.

Acho que posso afirmar, sem errar, que as discussões sobre sexualidade (e também sobre gênero) promovidas através dos grupos de trabalho, mesas redondas, simpósios temáticos e minicursos nos CISO e REA/ABANNE propulsaram a produção de pesquisas sobre sexualidades nas duas regiões na década de 2000, a ponto de viabilizar a realização exitosa desses eventos mais específicos na década de 2010 - o terceiro movimento teria, assim, se desdobrado no quarto movimento?

\section{Quinto Movimento: Laura Moutinho}

Juntamente com Laura Moutinho, creio que fomos, de certo modo, pioneiros ao longo da década de 2000, agregando em nossos GTs muitos/as pesquisadores/as de todos os níveis de formação acadêmica que faziam pesquisas no campo das sexualidades (e também dos estudos de gênero) de forma mais ou menos isolada nas regiões Nordeste e Norte. Quando iniciei minhas atividades na UFPI, havia um único trabalho acadêmico, um TCC da área do serviço social, sobre sexualidade, mais especificamente sobre os espaços de sociabilidade homossexuais em Teresina. Não havia nenhum outro trabalho acadêmico ou texto publicado sobre o assunto na grande área das Humanidades em todo o Piauí. Atualmente, o estado conta com uma série já volumosa de estudos sobre sexualidades, alguns orientados por mim e muitos outros, orientados em diversas áreas do conhecimento, além de eventos organizados com importantes apoios.

Em 2003, participei pela primeira vez de um evento de antropologia no Brasil, a VII ABANNE (ainda não se chamava REA), realizado na Universidade Federal do Maranhão, com um minicurso intitulado Identidades Culturais e Culturas (Homo)Sexuais. O minicurso fez muito sucesso, de modo que foi preciso trocar de sala para comportar a enorme demanda. Para mim, isso parecia ser a primeira prova de que havia jovens pesquisadores/as interessados/as nessa temática que muito provavelmente tinham dificuldade para encontrar, em suas instituições de origem nas duas regiões, interlocutores/as acadêmicos para orientá-lo/as - a volonté de savoir se mostrava com força. A palestra de Luiz Mott foi a mais concorrida do evento, auditório lotado, pessoas sentadas no chão, falas polêmicas, discursos inflamados... sobre "a homossexualidade no reino animal". No final, Mott veio até onde eu estava, cumprimentou-me secamente e sem mais delongas chamou a minha atenção por não tê-lo convidado para a Semana da Diversidade Sexual de Teresina. Ficou enciumado por eu ter convidado o Prof. Peter Fry para a abertura do evento, palestrando ao lado do novo governador do Piauí, Wellington Dias, do PT, e não ele. Alguns anos mais tarde, ele iria ao Piauí para participar de uma Feira do Livro e faria questão que eu o apresentasse para um público enorme composto principalmente por estudantes e professores dos ensinos fundamental e médio.

O meu minicurso da ABANNE foi repetido no CISO de 2003, realizado na Universidade Federal de Sergipe, com o título Identidades Culturais e Culturas Identitárias (Homo)Sexuais. Novamente, o sucesso foi grande, sendo preciso aqui também uma mudança de sala para comportar a quantidade de participantes, geralmente estudantes de graduação e pósgraduação. Percebi que seria preciso, nas edições seguintes desses eventos, apresentar propostas de grupos de trabalho (para além dos grupos de trabalho já existentes sobre gênero) para agregar as pesquisas especificamente sobre sexualidades que pareciam estar despontando isoladamente em vários estados das duas regiões. Nos dois anos que se seguiram, muitos/as desses/as estudantes que participaram dos minicursos me convidaram para eventos e bancas em suas instituições de origem. Hoje, alguns/mas são pesquisadores/as em diversas instituições do Brasil e de outros países. 
Em razão da parceria com o CLAM, coordenei GTs com Laura Moutinho (àquela altura, pesquisadora agregada ao CLAM) nas edições do CISO de 2005, realizada no Pará (GT intitulado Sexualidades, Cultura e Identidade); de 2007, realizada em Alagoas (Sexualidades, Cultura e Identidade); de 2009, realizada em Pernambuco (Sexualidades, Cultura e Identidade); e de 2012, realizada no Piauí (Culturas Corporais, Sexualidades e Transgressões: novas moralidades em debate na erados Direitos Humanos).

Quanto à REA/ABANNE, coordenei o GT intitulado Sexualidades, Cultura e Identidade juntamente com Berenice Bento na edição de 2007, realizada em Sergipe; o GT intitulado Sexualidades, Culturas e Identidades, novamente com Laura Moutinho, na edição de 2009, realizada no Rio Grande do Norte; o GT intitulado Culturas Corporais, Sexualidades e Reconhecimento: novas moralidades em debate, com Laura Moutinho, na edição de 2013, realizada no Ceará; e, enfim, o GT intitulado Sexualidades, Moralidades e Direitos, também com Laura Moutinho, na edição de 2015, realizada em Alagoas; além de apresentar uma comunicação num GT da edição de 2011, realizada em Roraima (não houve proposta de GT sob a minha coordenação nesse ano de 2011).

Para a minha surpresa, depois do bom desempenho da participação nos CISO de 2003 e 2005 e na ABANNE de 2003, a proposta de GT que encaminhei com Laura Moutinho para a edição de 2005 da ABANNE, realizada em conjunto no Amazonas e em Roraima, não foi aceita, nem a proposta de minicurso que seria ministrado juntamente com o Juiz Federal (hoje Desembargador) Roger Raupp Rios. Eu e Laura Moutinho ainda coordenamos GTs em diversas edições da Reunião Brasileira de Antropologia (RBA) nas décadas de 2000 e 2010.

Cabe lembrar que, na edição da REA/ ABANNE de 2009, houve um fórum que, de algum modo, procurou sintetizar as pesquisas sobre sexualidades num âmbito mais amplo, para além das regiões Nordeste e Norte, já que o evento tinha deixado de ser oficialmente regional e passado a ser internacional. Essa síntese parece ter sido incorporada e apresentada de maneira mais consolidada, por um lado, num pré-evento ocorrido no âmbito da Reunião Brasileira de Antropologia, edição de 2012, realizada em São Paulo, e por outro, em algumas publicações, em particular de autoria de Júlio Simões, Sérgio Carrara e Laura Moutinho, do início da década de 2010. O mesmo se repetiu num fórum organizado por Júlio Simões durante a última edição da REA/ ABANNE, em 2015, em Alagoas (CARRARA;SIMÕES, 2007; MOUTINHO, 2014; SIMÕES ; CARRARA, 2014).

Em todos os GTs coordenados nos CISO e nas REA/ ABANNE, o número de propostas de comunicação passou de quarenta, sendo selecionadas para apresentação vinte propostas em média (de acordo com as normas de cada edição dos eventos). Nas primeiras edições, as propostas eram em sua grande maioria de jovens pesquisadores/as das regiões Nordeste e Norte. Mas, a partir de meados da década de 2000, o número de propostas de pesquisadores/as do eixo Sul-Sudeste aumentou, a ponto de, em algumas edições, se igualar ao número de propostas das regiões Nordeste e Norte.

\section{Sexto Movimento: Outras Gerações}

Os GTs coordenados ao longo da década de 2000 nesses eventos "regionais" agregaram dezenas de jovens pesquisadores/as, alguns/mas deles/as sendo acompanhados/as desde a graduação (quando apresentavam pôsteres) até a atividade como pesquisadores/as institucionalizados/as (geralmente, em universidade públicas), passando pelo mestrado e pelo doutorado. Esses trabalhos geraram publicações em periódicos ou livros, promovendo a visibilização das pesquisas feitas nas duas regiões. A partir da década de 2010, muitos/as desses pesquisadores/as que apresentaram trabalhos nos GTs passaram agora a ter as suas próprias propostas de GTs e mesas redondas aceitas nos mais diversos eventos, principalmente nos eventos temáticos ou específicos citados acima (Enlaçando Sexualidades, Desfazendo Gênero, Congressos da $\mathrm{ABEH}$, dentre outros).

EntreRios - Revista do PPGANT -UFPI -Teresina • Vol. 3, n. 1 (2020) 
Passaram também a liderar grupos de pesquisa em suas instituições de atuação profissional, a orientar pesquisas de iniciação científica e trabalhos de conclusão de curso em todos os níveis e a organizar eventos sobre sexualidades.

Assim, o campo de estudos sobre sexualidades nas duas regiões - bem mais na região Nordeste do que na região Norte - foi-se ampliando e consolidando. Na edição de 2015 da REA/ABANNE, houve um interessante fórum reunindo jovens pesquisadores/as do campo das sexualidades que fizeram questão de demarcar suas diferenças em relação aos/às estudiosos/ as mais experientes (para não dizer mais "antigos"), geralmente os/as seus/suas exorientadores/as, o que parece ser um sinal de como o campo está se diversificando e se complexificando, inclusive no Nordeste (um pouco menos no Norte, onde as pesquisas ainda são incipientes e muito localizadas no Pará).

\section{Sétimo Movimento: a SBPC eo ENUDS}

Eventos mais pontuais tiveram certa importância para a instigar a reflexão sobre as sexualidades nas regiões Nordeste e Norte. Penso particularmente em edições, ao longo da década de 2000, dos encontros regionais da Sociedade Brasileira para o Progresso da Ciência (SBPC) - Pará/2004, Amazonas/2004, Piauí/2004, etc. Durante a gestão da Prof ${ }^{a}$ Miriam Grossi à frente da Associação Brasileira de Antropologia (ABA), a edição do Congresso Nacional da SBPC realizada em 2005, no Ceará, contou com um amplo conjunto de atividades sobre gênero e sexualidades, uma inovação para um evento desse tipo. Eu participei com uma palestra sobre violência e discriminação por orientação sexual no Piauí (GONTIJO, 2006). Naquele momento, eu era também vice-presidente da comissão de ensino de antropologia da ABA, sob a presidência da Prof ${ }^{a}$ Yvonne Maggie.

Um outro evento de relevância considerável para as reflexões sobre as sexualidades nas regiões Nordeste e Norte foi o Encontro Nacional Universitário da Diversidade Sexual (ENUDS), evento anual que congregava estudantes e pesquisadores/as de todo o Brasil. A edição de 2008, realizada no Pará e organizada pelo Grupo Orquídeas - Movimento Universitário em Defesa da Diversidade Sexual, é citado por interlocutores de minhas pesquisas realizadas em Belém como um marco para alavancar as reflexões sobre sexualidades no estado. Em diversas universidades brasileiras, foram criados, na esteira do Programa Brasil sem Homofobia (primeira metade da década de 2000), grupos universitários de "conscientização homossexual", dentre os quais o Orquídeas, que surgiu em 2007. Muitos/as integrantes desse grupo cursavam Ciências Sociais na UFPA e, hoje em dia, são mestres/as ou doutores/as em Antropologia, tendo realizado pesquisas sobre sexualidades na Amazônia e alhures. Percebi, em minhas pesquisas, que antes do ENUDS, as reflexões no Pará eram poucas e pontuais (GONTIJO \& ERICK, 2016). A partir do ENUDS, começaram a surgir polos de produção acadêmica sobre sexualidades, principalmente na UFPA. Talvez a partir de - ou juntamente com - iniciativas como a desses grupos criados nas universidades é que tenham despontado, na segunda meta da década de 2010, grupos e eventos como aqueles que agregam atualmente estudantes indígenas, inclusive discutindo questões relativas à diversidade sexual e de gênero (como os Encontros Nacionais de Estudantes Indígenas, ENEI).

\section{Oitavo Movimento: o SEXGEN}

No Piauí, o primeiro grupo de pesquisas sobre sexualidades foi o que eu lidero até os dias de hoje, Sexualidades, Corpo e Gênero (SEXGEN). Quando fui redistribuído para o Pará, o grupo foi cadastrado na UFPA, sendo também o primeiro grupo com essa temática no estado. Hoje, o grupo funciona em rede, com atividades na Universidade Federal do Piauí (UFPI) e na Universidade Federal do Oeste do Pará (UFOPA), 
Além da sede na UFPA. Na UFPI, três ex-orientandas do Programa de Pós-Graduação em Antropologia e Arqueologia, juntamente com outras ex-alunas também do mesmo curso, atualmente todas professoras, levam adiante uma série de ações, como encontros para discussão de textos, organização de eventos, produção de artigos para publicação, etc. - em 2019, foi organizado um evento na cidade de Parnaíba, no litoral piauiense, com a presença de pesquisadores/as das áreas de corporalidades, raça, sexualidades e gênero, como Fátima Lima (UERJ) e Djamilla Ribeiro, inclusive pesquisadoras transexuais ou transgêneres. Eu participei como palestrante. Na UFOPA, as Profas. Carla Ramos e Raiana Ferrugem orientam pesquisas sobre a temática, com forte diálogo comigo. Nessa Universidade, situada em Santarém, ministrei uma disciplina para o curso de graduação em Antropologia e Arqueologia sobre a diversidade sexual e de gênero em 2015, dentre outras ações, como será relatado mais adiante. Na UFPA, a discussão sobre sexualidade era tradicionalmente feita no âmbito do Grupo de Estudos e Pesquisas Eneida de Morais (GEPEM), criado em 1994 por iniciativa das Profas. Edna Castro, Rosa Acevedo Marín e Luzia Álvares. O grupo é o mais ativo da região Norte.

\section{Nono Movimento: as dissertações e os relatórios de iniciação científica}

Com a minha atuação na pós-graduação na UFPI, foi escrita a primeira dissertação de mestrado sobre homossexualidades no Piauí (mais especificamente sobre o "mercado rosa" que estava despontando em Teresina, segmento de mercado voltado para o então chamado "público LGBT"). Embora a discente fosse economista de formação e a dissertação tenha sido produzida num curso de Mestrado em Políticas Públicas, a pesquisa teve um acentuada caráter etnográfico (SÁ; GONTIJO, 2006).

Em seguida, no âmbito do mestrado em Antropologia e Arqueologia (hoje, mestrado em Antropologia) foram elaboradas mais três dissertações orientadas por mim: Redes de Sociabilidades Gays em Teresina: lógicas e estratégias de pertencimento, de Ana Kelma Gallas Cunha, defendida em 2013; Significações a Respeito da Masculinidade entre Jovens Gays na Cidade de Teresina: fatores reguladores da sexualidade, de Daiany Caroline Santos Silva, também defendida em 2013; e Entre Redes: mulheres, afetos e desejos, de Pâmela Laurentina Sampaio Reis, defendida em 2015. No mesmo Programa de Pós-Graduação, foram defendidas mais duas dissertações sobre homossexualidades: Aquenda Mona! Travessia Etnográfica sobre a Experiência Drag Queen em Teresina, de Avelar Amorim, defendida em 2016 e orientada por Anna Paula Vencato, e Perdendo a Cabeça na Tontura: reflexões etnográficas no campo da pegação homoerótica em Teresina, de José Ricardo Fortes Sampaio, defendida em 2019 e orientada por Alejandro Labale - ambas as dissertações foram amplamente influenciadas pelas pesquisas de mapeamento que eu havia realizado no Piauí. Houve ainda uma dissertação defendida no mestrado em Enfermagem, em 2014, sobre idosos homossexuais a partir de uma pesquisa etnográfica que contou com a minha contribuição.

Orientei diversas estudantes de graduação em pesquisas sobre sexualidades no Piauí inicialmente, no contexto urbano de Teresina e, depois, com a temática da ruralidade e/ou da etnicidade. Orientei três trabalhos sobre as representações de possíveis cenas de práticas sexuais entre pessoas do mesmo sexo ou técnicas corporais sexuais nos grafismos rupestres de sítios arqueológicos piauienses - dois trabalhos de iniciação científica e um trabalho de conclusão de curso. Não me senti à vontade para publicar sobre esse último assunto, como já dito acima, mas eu e um dos estudantes participamos, com apresentação de comunicações em GTs, do XV Congresso da Sociedade de Arqueologia Brasileira, em 2009, em Belém. 


\section{Décimo Movimento: particularidades locais, mas teorias globais}

A impressão que tenho é que, nas regiões Nordeste e Norte, as pesquisas realizadas por pesquisadores/as locais na década de 2000 e no início da década de 2010 se serviam do arcabouço teórico e da metodologia utilizados nas pesquisas feitas no eixo Sul-Sudeste. As temáticas também se inspiravam muito nas temáticas abordadas nas pesquisas feitas nos grandes centros de produção, como Universidade Estadual de Campinas, Universidade de São Paulo, Universidade Federal de Santa Catarina e Universidade do Estado do Rio de Janeiro, dentre outras (geralmente, pesquisas sobre os espaços de sociabilidade). Isso se deve talvez à necessidade de promover diálogos com os/as pesquisadores/as mais renomados/as e/ou experientes no campo. Mas, isso também pode ter a ver com o fato de que muitos/as desses/as pesquisadores/as do Nordeste e do Norte tinham feito cursos (graduação, pós-graduação, etc.) junto a pesquisadores/as do eixo Sul-Sudeste. A partir da década de 2010, parece começar a haver inovações temáticas, mais condizentes com as realidades locais. Mais timidamente, notam-se também inovações metodológicas. O arcabouço teórico, a meu ver, ainda está marcadamente determinado pelo que se produz no eixo Sul-Sudeste.

\section{Décimo-Primeiro Movimento: O Programa de Pós-Graduação em Antropologia e Arqueologia/UFPI}

Tendo em mente esses "movimentos" e a experiência acumulada ao longo da década de 2000 no ensino, na pesquisa e na extensão, passo a expor, a partir de agora, as atividades desenvolvidas após a criação do Programa de Pós-Graduação em Antropologia e Arqueologia (PPGAArq) da UFPI - atividades que têm a ver com um certo amadurecimento acadêmico adquirido com essa experiência e que aceleraram os "movimentos" culminando na redistribuição em 2013 para a Universidade Federal do Pará.

No final da década de 2000, a UFPI estava a todo vapor, em grande parte graças ao REUNI e em menor escala, a recursos de emendas parlamentares. No Departamento de Ciências Sociais, docentes recém-contratados/as ou recém-chegados/as de cursos de doutoramento estavam se empenhando na qualificação de sua produção científica, na reformulação de currículos de cursos de graduação, em particular do curso de Ciências Sociais e sobretudo, na elaboração de propostas de cursos novos - de graduação e de pós-graduação (lato sensu e stricto sensu). Foi nesse contexto de ebulição que surgiram os cursos de graduação e de mestrado em Ciência Política (este último, em associação com a UNICAMP) - e o consequente desmembramento dessa área disciplinar com a criação do Departamento de Ciência Política - e o curso de mestrado em Sociologia. Entre os dois, foram inaugurados o curso de graduação em Arqueologia (reunindo docentes das Ciências Humanas e das Ciências da Natureza) e o curso de mestrado em Antropologia e Arqueologia - cabe ressaltar a importância da Prof ${ }^{a}$ Maria Lídia Medeiros de Noronha Pessoa na liderança da comissão que elaborou a proposta de curso novo, sem a qual o curso dificilmente teria sido criado.

Em setembro de 2008, fui a Belém para participar do Encontro da Rede Feminista do Norte e do Nordeste (REDOR) e acabei participando também, como ouvinte, de um evento organizado por docentes da área de antropologia do Programa de Pós-Graduação em Ciências Sociais. O evento, intitulado Antropologia em Foco: campos interdisciplinares para o estudo do outro tinha como objetivo produzir reflexões para embasar uma proposta de curso de antropologia em níveis de mestrado e doutorado na perspectiva de Franz Boas dos "quatro campos" ou four fields, ou seja, antropologia social, arqueologia, bioantropologia e antropologia linguística. $O$ evento me chamou muito a atenção, por se tratar de uma perspectiva que me interessava cada vez mais, como vimos acima. Foi durante esse evento que recebi um telefonema do Reitor da UFPI, Prof. Luiz dos Santos Júnior, para informar que o nosso Programa tinha sido aprovado em uma reu- 
nião da CAPES e que começaria a funcionar em 2009. A notícia foi acolhida pelos/as colegas da UFPA com muito carinho, pois eles iriam enviar também uma proposta semelhante à nossa, embora bem mais ousada e robusta. A proposta da UFPA foi aprovada no ano seguinte e os cursos começaram em 2010.

O PPGAArq iniciou as suas atividades, portanto, em 2009 sob a minha coordenação, contando com duas áreas de concentração - Antropologia e Arqueologia - e três linhas de pesquisa - Marcadores Identitários na Contemporaneidade (para lidar com as múltiplas articulações dos marcadores sociais da diferença, sobretudo em contextos urbanos), Memória $e$ Territorialidades (para lidar com as ruralidades e a etnicidade) e Cultura Material e Conservação de Sítios Arqueólogicos (para lidar com a análise de vestígios arqueológicos e os processos de patrimonialização decorrentes). O PPGAArq se queria interdisciplinar e contava com docentes de diversos departamentos da UFPI, sobretudo do Departamento de Ciências Sociais e do Curso de Arqueologia e Conservação de Arte Rupestre, mas também com docentes colaboradores da Fundação Museu do Homem Americano (nomeadamente, Niède Guidon e Gisele Daltrini Felice) e do Museu Paraense Emílio Goeldi, de Belém (Edithe Pereira). Em seguida, um concurso foi realizado e quatro novos docentes foram contratados para a área de Antropologia, todos de fora do Piauí.

O Programa retomava assim um processo histórico que havia sido interrompido na década de 1980, na tentativa de associar a antropologia e a arqueologia (GONTIJO, 2015). Embora o que se almejava, nessa virada da década de 2000 para 2010, era a perspectiva especificamente boasiana, o Programa tomou rumos próprios. Pesquisadores/as de ambas as áreas se juntaram para criar o Programa em razão das dificuldades que tinham, isoladamente, para criar Programas específicos de suas áreas respectivas. Não havia projetos em comum que vinculassem as duas áreas, nem foi possível montá-los ao longo dos primeiros anos de funcionamento do Programa, talvez por falta de interesse da maioria dos/as pesquisadores/as em razão de suas agendas próprias de pesquisa, com algumas poucas exceções, dentre as quais, eu mesmo. O PPGAArq foi a ocasião que eu encontrei para reforçar o diálogo com as teorias arqueológicas, o que só veio a ocorrer de fato e com mais vigor na UFPA.

A inauguração do PPGAArq merece ser lembrada aqui: convidamos a Presidente da Sociedade de Arqueologia Brasileira (SAB), Prof ${ }^{a}$ Denise Pahl Schaan, da UFPA, e o Presidente da Associação Brasileira de Antropologia (ABA), Prof. Carlos Caroso, da Universidade Federal da Bahia (UFBA), para uma aula campal no sítio arqueológico da Pedra Furada, no Parque Nacional da Serra da Capivara, onde se encontra a Fundação Museu do Homem Americano (FUMDHAM), parceira do PPGAArq, a quase $600 \mathrm{~km}$ de Teresina. Foi um momento marcante. Todos os discentes da primeira turma e docentes do Programa, além dos/as convidados/as, dentre os quais, a Prof ${ }^{a}$ Fátima Tavares (UFBA) e outros/as pesquisadores/as atuantes no Piauí não vinculados ao Programa e discentes de graduação em ciências sociais, viajaram em ônibus cedido pela UFPI, passando pela primeira capital do estado, Oeiras, rumo ao Parque, onde todos/as ficaram hospedados num abrigo.

No final do ano em que o Programa iniciou suas atividades, concorremos a um Edital da CAPES do Programa Nacional de Cooperação Acadêmica "Novas Fronteiras" (PROCAD-NF) e tivemos a proposta aprovada para ser implementada a partir de 2010. O PROCAD previa a cooperação entre um Programa novo ou pequeno com um Programa mais experiente. Uma pesquisa seria desenvolvida pelos/as pesquisadores/as envolvidos na proposta de ambos os Programas, docentes fariam estágios de pós-doutorado na instituição do Programa mais experiente e discentes poderiam fazer estágios de Mestrado sanduíche em ambos os Programas.

A cooperação teve a duração de quatro anos (de 2010 a 2013, renovada por mais alguns meses) e os recursos liberados foram da ordem de trezentos mil reais para serem utilizados pelos dois Programas na forma de passagens e diárias para missões de pesquisa, bolsas e auxílios para docentes (estágios de pós-doutorado) e discentes (estágios de mestrado sanduíche) para as mis- 
sões de estudo, fomento, publicações, organização de eventos, etc. Ao longo dos quatro anos, foram envolvidos seis docentes e cinco discentes do PPGAArq e cinco docentes e dois discentes do Programa parceiro para o desenvolvimento de pesquisas sob o tema das Dinâmicas Sociais e Ruralidades Contemporâneas: análise dos impactos culturais locais de diferentes propostas de desenvolvimento econômico no Piauí (apicultura, soja, biodiesel e celulose) em cooperação com o Programa de Pós-Graduação de Ciências Sociais em Desenvolvimento, Sociedade e Agricultura (CPDA) da Universidade Federal Rural do Rio de Janeiro (UFRRJ).

No âmbito desse projeto "guarda-chuva", eu me associei ao Prof. John Comerford (que, àquela altura, ainda se encontrava no CPDA/UFRRJ, atualmente no PPGAS/UFRJ) e à Prof ${ }^{a}$ Maria José Carneiro para desenvolver uma pesquisa sobre gênero junto a famílias rurais. No entanto, quando da primeira sondagem em campo, percebi um universo ainda a ser descortinado pela antropologia brasileira: as experiências da diversidade sexual e de gênero no meio rural ou, simplesmente, em pequenas cidades interioranas e comunidades rurais. Uma guinada se deu em meus interesses de pesquisa nesse momento. O projeto que ficou sob a minha responsabilidade se intitulou Os Campos dos Desejos: Família, Gênero e Sexualidade no "Mundo Rural" Piauiense e contou, de 2010 a 2012, com recursos do Edital MCT/CNPq 14/2010-Universal e com uma bolsa de Iniciação Científica do mesmo Conselho Nacional de Desenvolvimento Científico e Tecnológico (CNPq) para uma estudante do curso de graduação em Ciências Sociais da UFPI. A pesquisa se inseriu nas atividades do grupo de pesquisa Sexualidades, Corpo e Gênero (SEXGEN), liderado por mim.

Além da diversidade de biomas e ecossistemas complexos dessa região situada entre a Amazônia, o Semiárido e o Cerrado, o Piauí apresenta áreas habitadas por povos tradicionais, como as inúmeras comunidades quilombolas, de pescadores e marisqueiros, quebradeiras de coco, extrativistas da carnaúba e populações camponesas diversificadas que manejam seus territórios de múltiplas formas, segundo saberes específicos. O momento de grandes transformações culturais, sociais e econômicas, promovido pelo maior alcance das políticas governamentais na década de 2000 fez com que se aguçassem questões relativas à construção social do território e de identidades de grupos locais. Dimensões diferenciadas de acesso ao mercado e às novas tecnologias se entrecruzavam, assim, em um espaço recortado por redes de institucionalidades múltiplas. O processo de reconhecimento de direitos associados a territorialidades distintas articulava-se à organização de movimentos sociais no campo incorporando dimensões étnicas, geracionais e de gênero. Ao mesmo tempo, se acelerava a inserção do Piauí na economia mundial sob a égide do desenvolvimento, ocasionando áreas de conflito social e ambiental baseados em disputas por recursos naturais e por terras. Foi nesse contexto que se inseriu a pesquisa que tratou mais particularmente dos "desvios e divergências" relacionados às identidades de gênero hegemônicas em comunidades rurais piauienses.

Tratar-se-ia, assim, nesta pesquisa, de cartografar as estruturas das famílias rurais piauienses envolvidas, direta ou indiretamente, nos grandes projetos de desenvolvimento econômico, sociografar a realidade cotidiana das famílias e etnografar as relações familiares, conjugais e parentais, tendo como mote a ideia de que as famílias que vivem no mundo rural estariam passando por importantes modificações em suas estruturas, o que poderia estar vinculado, dentre outros fatores, às consequências da efetivação do ideal desenvolvimentista no Piauí.

Um novo direcionamento foi dado ao projeto inicial a partir de conversas com uma estudante da primeira turma do Programa de Pós-Graduação em Antropologia e Arqueologia da Universidade Federal do Piauí, Maria Elza Soares da Silva, que vinha estudando os "parceiros" (termo usado pelos camponeses em questão) envolvidos no projeto de "assentamento rural privado" (termo oficial) da Fazenda Santa Clara, na região do semiárido piauiense, no centro-sul do estado. 
A estudante encontrou, em sua "etnografia da terra prometida" ${ }^{10}$, famílias de formatos bastante diferenciados, que dificilmente se encaixavam nos modelos tradicionais de famílias rurais descritas pela vasta literatura existente nas ciências humanas brasileiras (e estrangeiras) sobre o assunto.

Apesar de não ser o foco da pesquisa da estudante, ela se deparou, no convívio com a comunidade estudada, com o caso de uma mulher transexual que exercia certa influência na gestão política dos conflitos na comunidade. E o mais interessante era o fato de que, aparentemente, a mulher transexual em questão não seria alvo de forte preconceito por parte de homens e mulheres da comunidade, fossem eles, de um lado, parceiros ou, de outro, empregados da administração da empresa gestora do empreendimento de assentamento. Esse fato foi confirmado por outra estudante da segunda turma do mesmo curso.

A partir dessas conversas, decidi dar ênfase em minha pesquisa aos "desvios e divergências" (VELHO, 1985) relativos às construções identitárias no mundo rural - em particular, no que diz respeito à diversidade sexual e de gênero - para apreender os significados das relações sociais globais vigentes nesse contexto contemporâneo de grandes transformações sociais e culturais - vinculadas em particular, em nosso caso, à implantação da lógica do agronegócio no Piauí. A pesquisa voltou-se então para a maneira como os "padrões hegemônicos de normalidade" eram (re)interpretados e experimentados (talvez às avessas) em contextos culturais distintos, criando novos sujeitos imbuídos de novas moralidades e (até mesmo) constituindo novas legalidades. Para tanto, servi-me de narrativas de trajetórias de vida $\mathrm{dos} /$ as interlocutores/as entrevistados/as em diversas comunidades rurais piauienses com o objetivo de captar a lógica das discursividades do desenvolvimentismo e da heteronormatividade ${ }^{11}$ e suas consequências no âmbito da construção de subjetividades nesse contexto.

Dentre as diversas pessoas que colaboraram com a pesquisa, além da mulher transexual, Vanessa (nome fictício), da Fazenda Santa Clara, estão Kátia Tapety, ex-vice-prefeita de Colônia do Piauí, que se auto-reconhece como travesti, uma outra travesti de Picos, Nego Pinto (nome fictício), uma liderança quilombola que se auto-reconhece como gay afeminada, um casal de mulheres camponesas de um assentamento rural, e dois irmãos que se auto-reconhecem como gays de um outro quilombo piauiense. A partir dessas subjetividades, tentamos inferir sobre a operacionalização dos códigos de inteligibilidade que referenciam as relações de gênero, transformando-as nos "gêneros inteligíveis" de que trata Butler (2003), que pressupõem uma continuidade entre sexo/gênero/desejo/prática sexual. Assim, foi possível confirmar e "sublinhar a centralidade dos mecanismos sociais relacionados à operação do binarismo hetero/homossexual para a organização da vida social contemporânea" (MISKOLCI, 2009, p. 154).

Vanessa, além de residir num assentamento rural e se dizer "traveco" - "ser traveco é melhor que mulher" -, se diz também católica não praticante, negra e pobre: as relações de gênero e a sexualidade participam da organização das relações sociais e se articulam com outros eixos de diferenciação nessa empreitada (BRAH, 2006; PISCITELLI, 2008), como classe, categoria sócio-profissional, raça/ etnia, nacionalidade, religião, região de residência, etc. Este também é o caso de Kátia Tapety, primeira travesti eleita a cargo público no Brasil, negra, de origem camponesa, única herdeira de uma família de empreendedores rurais tradicionais, agente de saúde e parteira de "humanos e animais"... Assim também vive uma mulher transexual de Picos que, depois de passagem pelos grandes centros urbanos brasileiros, onde pôde entender sua travestilidade, voltou a sua terra natal e tornou-se uma liderança política respeitada.

10 A dissertação de mestrado da estudante teve por título “Etnografia da Terra Prometida: trajetórias sociais, conflitos e cotidiano dos/as camponeses/as parceiros/as da Brasil EcoDiesel - O caso da Fazenda Santa Clara, no Piauí" e foi defendida em março de 2011.

11 O termo teria sido cunhado pelo professor e crítico literário norte-americano Michael Warner (1993) para designar a normatividade heterocentrada do dispositivo de sexualidade. 
Enfim, a experiência de Nego Pinto, rapaz que, durante o dia, usa o nome masculino e, de noite, nome e roupas femininos, que se tornou importante liderança de um quilombo no centro do Piauí, demonstra também as complexas articulações de categorias.

Vanessa, Kátia, Nego Pinto - e também o casal de mulheres do assentamento e os irmãos gays quilombolas, por exemplo - com suas trajetórias ordinárias - por comparação às trajetórias consideradas como "extraordinárias" ou excepcionais, como as de Leila Diniz (GOLDENBERG, 1996), Janaína Dutra (SAMPAIO, 2011, 2015) ou Consuelo Caiado (KOFES, 2001) - permitiramme alcançar e entender alguns mecanismos de articulação entre as categorias de diferenciação e as estruturas que geram e reproduzem a heteronormatividade e as desigualdades a ela atreladas, assentando poderosas discursividades.

Mas, até mesmo num contexto de implantação de projetos de desenvolvimento econômico muitas vezes insensíveis às particularidades locais e à diversidade cultural e, por conseguinte, à diversidade sexual e de gênero, essas trajetórias pareciam demonstrar que havia lugar para arranjos que destoassem do modelo hegemônico e que negociações estavam sempre em jogo. Esses não eram casos pitorescos, mas casos comuns nesse momento de grandes transformações sociais e culturais e de fortes rupturas, como a pesquisa demonstrou. Em algumas publicações, apresentamos os primeiros resultados da pesquisa (GONTIJO, 2011, 2013, 2014, 2015b; GONTIJO; COSTA, 2012), que apontaram, como resultado da recensão bibliográfica e crítica, para o fato de que, apesar da consolidação dos campos de estudos sobre ruralidade, por um lado, e por outro, sobre gênero e sexualidade no Brasil, pouco (ou nada) tinham sido tratados, em ambos os campos, quaisquer aspectos relacionados à experiência sexual e à diversidade sexual e de gênero nas zonas rurais brasileiras.

Não demorou para que eu percebesse, no desenrolar da pesquisa, que as lacunas diziam respeito a algo mais amplo, pois incluíam os estudos sobre etnicidade e etnologia indígena, ou seja povos e populações tradicionais. A pesquisa bibliográfica foi desenvolvida ainda no âmbito de um pequeno estágio de pós-doutorado realizado junto ao Programa de Pós-Graduação de Ciências Sociais em Desenvolvimento, Agricultura e Sociedade da Universidade Federal Rural do Rio de Janeiro sob a supervisão da Prof ${ }^{a}$ Eli Napoleão de Lima. Reproduzo aqui um longo trecho das considerações finais de um dos artigos publicados já na UFPA, em coautoria com um orientando de iniciação científica (GONTIJO; ERICK, 2015, p.32-34):

Assim, concluem-se as pesquisas bibliográficas realizadas até o momento percebendo que, no que diz respeito aos estudos rurais, parece que a maior parte dos artigos e textos analisados estão ora voltados para a organização social vinculada aos aspectos econômicos da vida no campo, ora voltados para as questões morais relativas à família e aos arranjos familiares camponeses - o gênero aparece quase sempre na forma da mulher trabalhadora e/ ou militante ou dos papéis familiares.

No que diz respeito aos estudos de gênero e sexualidade, quando há articulação com a ruralidade, nota-se um grande número de artigos e textos que abordam, num primeiro momento, a condição da mulher camponesa (reprodutora e eventualmente produtora), às vezes vinculada aos movimentos sociais no campo, e/ou, em seguida, as relações de poder que permeiam as relações de gênero e as transformações dessas relações no mundo rural contemporâneo. A sexualidade (a)parece relegada à vida urbana como um "indizível das sociedades camponesas", para parafrasear Ferreira [...].

A sexualidade e, mais particularmente, a diversidade sexual e de gênero e as práticas sexuais que podem se tornar marcadores sociais da diferença interseccionalizados nas pesquisas sobre o mundo rural ou na etnologia indígena ou nos estudos de realidades quilombolas, caboclas e ribeirinhas não teriam se transformado em objetos de estudo per se por diversas razões, não necessariamente por uma suposta incapacidade dos pesquisadores em perceber sua importância para a compreensão das relações sociais marcadas pelas ruralidades, pela etnicidade ou pela regionalidade. Talvez a principal dessas razões seja a própria agenda de pesquisas, tanto nos estudos rurais ou nos estudos étnicos ou sobre realidades interioranas, como nos estudos de gênero e sexualidade, pau- 
tada por outros interesses de pesquisa ligados a certas tradições intelectuais (muitas vezes, a montagem da agenda se faz de acordo com demandas oriundas dos mais diversos pontos do campo de força em jogo nas Ciências Sociais) - no caso dos estudos rurais, em algumas tradições intelectuais que buscam entender as sociedades camponesas como sistemas sociais específicos, a economia e a política se tornam dimensões mais privilegiadas do que a sexualidade, entendida, esta última, como secundária $[\ldots]$.

No caso da etnologia indígena, Fernandes apontou, em sua tese recém-defendida em outubro de 2015, para as consequências ético-políticas envolvidas no reconhecimento da existência da prática não ritual da diversidade sexual em contextos indígenas brasileiros [...]. Em outras realidades indígenas latino-americanas ou norte-americanas, parece haver uma certa tradição de estudos sobre a sexualidade [...]. [...].

Embora historicamente as Ciências Humanas e, em particular, as Ciências Sociais e a Antropologia, venham deixando de lado esses aspectos da vida social no meio rural e interiorano ou em situações etnicamente diferenciadas problematizados aqui, percebe-se que, também historicamente, outros campos de produção de saberes e conhecimentos, como a literatura brasileira consagrada ou as artes plásticas celebradas, estão repletos de referências (muitas vezes explícitas) à sexualidade do camponês ou do homem que vive no campo, do indígena ou do africano do interior do país, do caboclo e do ribeirinho amazônida e do interiorano em geral. [...].

No entanto, é sabido que as Ciências Humanas se constituíram, enquanto ciências, como legítimas provedoras de "verdades" sobre o mundo, por oposição à literatura, esta relegada ao campo da "ficção" e, eventualmente, da produção de informação despreocupada com as "verdades", como já era apontado pela crítica pós-moderna [...]. Coube às ciências, assim, a instituição do que seria bon à penser; e à literatura e às artes plásticas, o "resto", a saber a sexualidade no mundo rural ou nos contextos interioranos e situações etnicamente diferenciadas, dentre outros temas.

Tratou-se, então, em nossas pesquisas - assim como naquelas de Fernandes [...] ou nas de Tota [...] -, de refletir, a partir de uma perspectiva desconstrutivista atenta aos efeitos da "analítica da normalização" [...], ao modus operandi dos biopoderes [...] e das tecnologias de gênero [...], sobre as trajetórias e experiências de sujeitos nada conformes àquelas que encontramos comumente nos livros de histórias sobre eles, sobre seus territórios, sua economia, sua organização social e suas relações de parentesco, sua mobilização política, sua moralidade, sua religiosidade, seus ritos e mitos... em que nunca são levados em conta seus corpos desejantes e desejados ou seus "afectos mal-ditos" (Ferreira, 2006), como se esses sujeitos "só" reduzissem sua existência à reprodução de suas tradições.

$[\ldots]$.

Os estudos rurais, assim como os estudos sobre realidades interioranas, contextos indígenas e etnicamente diferenciados, deixaram de lado (ou abordaram tangencialmente), durante muito tempo, essas temáticas consideradas periféricas, por um lado, por não tratarem da relação do camponês ou interiorano com sua produção, privilegiando-se, assim, os estudos sobre economia doméstica, conflitos agrários, sindicatos rurais, migrações, dentre outros - isso se deve, talvez, à contaminação dos estudos rurais pelos ideais desenvolvimentistas e heteronormativos... ou, por outro lado, simplesmente, porque essas temáticas não faziam parte da agenda de pesquisas naqueles momentos; ou, enfim, por não considerarem relevantes os discursos sobre a sexualidade proferidos por indígenas e quilombolas para o entendimento das cosmologias locais.

Quando despontam sujeitos que vivenciam o seu direito à liberdade de escolha e que destoam dos sujeitos com comportamentos "funcionais", tidos como "padrão", são logo taxados de "desviantes" [...]. Assim, no que diz respeito à diversidade sexual e de gênero, os mundos rural e interiorano amazônicos e os contextos indígenas e etnicamente diferenciados estariam apresentando uma ruptura com uma forte discursividade, aquela referente à longa tradição heteronormativa? Ou as relações observadas nos mundos rural e interiorano amazônicos e em contextos indígenas e etnicamente diferenciados seriam simplesmente o retrato - agora em cores - de uma realidade complexa e diversificada, muitas vezes negada pelos estudiosos dessas realidades e contextos? Ou o que vemos diz respeito simplesmente à dinâmica mesmo da vida social como um todo, em qualquer contexto? 
O trecho acima foi publicado quando eu já não me encontrava mais atuando no Piauí, mas no Pará, onde eu ia me voltar com mais afinco para as experiências da diversidade sexual e de gênero em situações etnicamente diferenciadas. No entanto, desde a experiência no âmbito do PROCAD, eu notava que, naquilo que eu estava chamando de interior ou interioridade, havia etnicização dos discursos apresentados no contexto da pesquisa de campo - e também racialização -, o que me levava a buscar a bibliografia adequada que me permitisse lidar com aquela produção discursiva. E não encontrava essas referências. No início da década de 2010, pesquisas realizadas no Piauí apontavam para a existência de grupos indígenas naquele estado, considerado, até então, como um dos poucos do Brasil em que não havia oficialmente povos indígenas. As discussões na UFPI encabeçadas por colegas que se voltavam para esses processos de emergência étnica aguçavam ainda mais a minha curiosidade para a diversidade sexual e de gênero entre povos indígenas.

A definição de interior e contexto interiorano (ou interioridade, como falei em alguns momentos) demorou um pouco para ser elaborada e ainda não está totalmente amadurecida, confesso. Os/As interlocutores/as usavam as categorias "interior" e "interiorano", que meus colegas dos estudos rurais tinham dificuldade em incorporar em suas análises. Apelei para textos de língua francesa e inglesa para ver como se tratavam essas questões em outras realidades nacionais, como na obra de Gray (2009), indicada pela Prof ${ }^{a}$ Miriam Adelman, da Universidade Federal do Paraná - e mais tarde, na coletânea organizada por Grey, Johnson e Gilley (2016). Acabei produzindo uma definição a partir da pesquisa de campo (emic), com inspiração nos estudos pós-coloniais (etic): o interior seria "um espaço-tempo que transita entre ruralidade e urbanidade, confundido pela dinâmica da etnicidade em contexto amazônico, nas figuras do cabloco e do ribeirinho, além do indígena e do quilombola" (GONTIJO; ERICK, 2015, p.31); quando utilizada pelos/as interlocutores/as, a categoria conotaria uma condição de subalternização à qual o mundo urbano teria submetido esse outro espaço-tempo, conferindolhe um valor geralmente negativo associado ao "atraso", ao "conservadorismo", à "tradição", etc.; assim, seria interior tudo o que não é representado pelos critérios da modernidade urbana, que, por associação, nada mais seria do que uma figura dominante de sujeição produzida pela situação colonial ou pelas colonialidades do poder e do saber.

O que passei a notar, no entanto, nas pesquisas no interior das regiões Nordeste e Norte, era a criatividade e a originalidade de modalidades e configurações de relações sociais que pouco tinham a ver com o que mostravam as pesquisas já consolidadas sobre sociabilidades homossexuais no Brasil e até sobre o dimorfismo sexual e o binarismo de gênero. Essa afirmação se verificaria quando de minhas pesquisas já no interior do Pará, como veremos mais adiante (GONTIJO; ERICK, 2017; GONTIJO ; FERNANDES, 2017; GONTIJO, 2017a).

Paralelamente a essa pesquisa, realizada com recursos do PROCAD e do Edital Universal, prossegui com a pesquisa relativa aos relacionamentos afetivos, configurações conjugais e arranjos parentais entre pessoas auto-reconhecidas como homossexuais nos contextos urbanos de Teresina e de São Luís, com bolsas de Produtividade em Pesquisa e Iniciação Científica. A ampliação da pesquisa para São Luís contribuiu para a elaboração de uma reflexão sobre as particularidades que poderiam surgir nos modos de relacionamentos em questão nessa região chamada comumente de Meio-Norte, que engloba o Piauí e o Maranhão, região de transição entre o Nordeste e o Norte. Essa já era a minha própria transição para a região Norte, creio, embora eu ainda não tivesse amadurecido essa ideia.

No PPGAArq, além de coordenar e ministrar disciplinas obrigatórias e optativas, orientei cinco dissertações, três delas sobre temas atinentes à diversidade sexual e de gênero, uma com uma temática relativa ao patrimônio cultural e, enfim, uma sobre a prática de "exortação de corpos" no interior do Piauí. Desses/as orientando/as, dois viriam a prosseguir no Doutorado (uma já concluiu e outro está em curso) e as outras três se dedicaram à docência no ensino superior (público ou privado). Uma sexta orientação foi iniciada na UFPI e terminada no Progra- 
ma de Pós-Graduação em Antropologia da UFPA. Além de me associar à Sociedade de Arqueologia Brasileira (SAB) e já ser sócio da Associação Brasileira de Antropologia (ABA) e da Sociedade Brasileira de Sociologia (SBS), contribuí para a filiação de diversos discentes e docentes do PPGAArq a essas entidades, através de cartas de recomendação. O PPGAArq se tornou sócio da Associação Nacional de Programas de Pós-Graduação e Pesquisa em Ciências Sociais (ANPOCS), embora discentes e docentes tivessem alguma dificuldade para participar efetivamente das atividades da entidade.

A partir de um certo momento, começou a ser apresentado, por parte das docentes mais experientes da área de arqueologia, um certo desejo em criar um Programa de Pós-Graduação que tivesse mais afinidade com o tipo de arqueologia que se fazia tradicionalmente no Piauí. Esse tipo de arqueologia era filiado por algumas pessoas à "Escola Francesa", em razão da influência de Niède Guidon e sua equipe, que tiveram formação na França; a nível mundial, trata-se da perspectiva processualista, mais preocupada com a cientificidade da produção e o aprimoramento de técnicas de investigação e de confirmação metodológica dos dados do que com as possibilidades interpretativas dos dados, a crítica da construção social das inferências arqueológicas, o questionamento das taxonomias usadas e/ ou produzidas pela arqueologia, o retorno da produção para as comunidades afetadas pela pesquisa e, enfim, a reflexividade na pesquisa. Em 2012, houve a criação do novo Programa de Pós-Graduação em Arqueologia (PPGArq), desmembrando-se em parte do Programa de Pós-Graduação em Antropologia e Arqueologia, o primeiro mais voltado para a conservação (química e física) de patrimônio arqueológico e a testagem de metodologias científicas - geralmente oriundas das Ciências da Natureza, donde a filiação do Programa ao Centro de Ciências da Natureza. No ano seguinte, o PPGAArq passaria a se chamar Programa de Pós-Graduação em Antropologia (PPGAnt), agora sem a área de arqueologia, embora alguns/mas docentes arqueólogos/as tenham permanecido no quadro do Programa por afinidade com a perspectiva mais em voga no Brasil, de reaproximação das áreas de arqueologia e antropologia.

Ao longo do tempo passado no Piauí, continuei com meus interesses de "mochileiro": viajar pelo mundo, sempre tentando associar o que observava pelo mundo agora com os ensinamentos da antropologia e da arqueologia. Entre 2002 e 2013, fui inúmeras vezes à Europa, percorri parte da Ásia e da Oceania em mais de uma ocasião, visitei países das Américas do Norte, Central e do Sul e me encantei com ilhas do Pacífico. O meu interesse em fazer das viagens ou de algum tema relativo à experiência turística da alteridade, um objeto de estudo antropológico, aumentava cada vez mais - uma viagem realizada em 2013 à Austrália e Papua Nova Guiné gerou um primeiro texto, publicado em 2017, sobre a relação que os trobriandeses têm nos dias de hoje com a memória dos/as antropólogos/as que por lá passaram e com os que estão atualmente fazendo pesquisa de campo na região (GONTIJO, 2017b).

Como disse mais acima, acompanhei o surgimento do Programa de Pós-Graduação em Antropologia da UFPA entre 2008 e 2010 e fiquei, a partir daí, sempre em contato direto com os/as colegas desse Programa, em especial Denise Pahl Schaan (em encontros de coordenadores/as de área e eventos de arqueologia e da SAB), Cristina Donza Cancela (em atividades de congressos e bancas de conclusão de trabalhos), Flávio Leonel Abreu da Silveira (em atividades de congressos), Jane Beltrão (em atividades de congressos e parcerias de pesquisa conjuntas) e Márcia Bezerra (em eventos de arqueologia e da SAB), além de outros/as colegas do Programa de Pós-Graduação em Ciências Sociais, tais como Denise Machado Cardoso, Telma Amaral, Heraldo Maués e Angélica Motta-Maués. A antropologia e a arqueologia da UFPA estavam sempre em meus pensamentos e contribuindo de alguma maneira com as minhas atividades acadêmicas.

Paralelamente, aproximei-me também, por afinidade teórica, de colegas do Programa de Pós-Graduação em Antropologia da UFBA, tais como Carlos Caroso e Fátima Tavares, além de alguns / mas outros / as do Programa de Pós-Graduação em Estudos Interdisciplinares em Mu- 
-lheres, Gênero e Feminismo (PPGNEIM). Em 2012, recebi o convite de colegas, tanto da UFBA, como da UFPA, para integrar o quadro docente dessas universidades.

Esses colegas vinham acompanhando o meu desempenho à frente do PPGAArq/UFPI Carlos Caroso por ter sido o consultor ad hoc enviado pela CAPES, juntamente com Emília Pietrafesa de Godoy (UNICAMP), no momento da elaboração de proposta de curso novo, Presidente da ABA quando da inauguração do Programa e parceiro de atividades em seguida; Denise Pahl Schaan por ter sido Presidente da SAB quando da inauguração do Programa e parceria de atividades em seguida. Por apreciarem o trabalho que eu vinha desenvolvendo, tanto no âmbito da gestão na pós-graduação, como no que concernia às pesquisas mais ou menos inovadoras que eu vinha empreendendo, fui convidado por colegas de ambas as instituições para ser redistribuído. Naquele momento, eu tinha muito interesse em trabalhar em um Programa maior, com curso de doutorado, de preferência no Nordeste ou no Norte e, enfim, com a perspectiva de diálogo com a arqueologia. Meus familiares gostavam muito de Belém e de Salvador e pouco me visitavam em Teresina, em particular os meus pais. Conversei com colegas da UFPI e obtive apoio total por parte de todos/as para a redistribuição. Restava saber para onde eu iria, UFBA ou UFPA.

A UFPA oferecia as melhores oportunidades para mim naquele momento, por se tratar de um Programa que nasceu com três áreas de concentração - antropologia social, arqueologia e bioantropologia - e tinha em projeto a criação de uma linha ou até mesmo uma área de antropologia linguística. Embora essa perspectiva antropológica norte-americana não tenha feito parte de minha formação inicial, que foi demasiado francesa, fazia alguns anos que eu buscava me aproximar dessas áreas por acreditar que era preciso pensar os meus temas de pesquisas inserindo-os no contexto da variabilidade humana em todos os seus aspectos, fossem eles sociais / culturais, biológicos, simbólicos ou históricos. A UFPA era o lugar privilegiado para instigar em mim e reforçar a interlocução com a arqueologia, com a bioantropologia e com a antropologia linguística. Além do mais, meus pais estavam pensando em se mudar do interior do Rio de Janeiro para Belém, por terem um enorme apego pela região amazônica.

A redistribuição da UFPI para a UFPA representaria, assim, o início de um período de consolidação de tudo o que tinha sido experimentado de forma performativa ao longo desses anos de atividades a partir da UFPI: o magistério superior; as aulas ministradas na graduação para tantos cursos diferentes; os cursos na pós-graduação (lato sensu e stricto sensu); as orientações de iniciação científica, monografia, tutoria, monitoria, mestrado e doutorado; as participações em bancas examinadoras de trabalhos de conclusão de curso e de concursos; as comissões diversas; as pesquisas desenvolvidas; a organização e a participação em inúmeros eventos; a gestão administrativa; etc.

\section{3 - Práticas Transformativas (após 2013)}

No dia 30 de novembro de 2012, quando eu me encontrava exatamente entre os dois postos de fronteira da Guatemala e de Honduras, a caminho do sítio arqueológico hondurenho de Copán, tocou o telefone celular e o número não identificado que aparecia era composto de uma série de zeros. Era a colega da UFPA, perguntando-me se eu tinha mesmo interesse em ser redistribuído para Belém. Não hesitei, respondi imediatamente que sim. O processo foi deslanchado e a consolidação da transformação, iniciada. Mudança de casa para refletir sobre outras ou novas "casas"...

As atividades junto ao Programa de Pós-Graduação em Antropologia (PPGA) da UFPA, minha nova casa (metonímica, sem aspas), tiveram começo em julho de 2013. Belém era considerada uma das cidades mais violentas do Brasil, em plena crise urbana naquele momento - crise que ainda persiste. Teresina arvorava o título de capital menos violenta do país e a cidade encontrava-se em expansão, com projetos urbanísticos sustentáveis em andamento. 
As diferenças, em relação à UFPI, eram gigantescas: a UFPA estava - e está ainda mais atualmente - entre as maiores universidades da América Latina; a maior da Amazônia, em todos os sentidos (quantidade de discentes, laboratórios, núcleos, cursos de todos os níveis, números da pesquisa, qualidade dos serviços prestados, forte internacionalização, inserção social impactante, etc); a UFPI era uma pequena universidade federal, uma das menores do Nordeste, com um número de discentes e docentes estabilizado, após o REUNI, muitas atividades sendo promovidas, pós-graduação em expansão, embora com pouca oferta de cursos de Doutorado, e processos de mudanças político-administrativas internas relativamente morosas que impediam a expansão da instituição. A UFPA já tinha sido desdepartamentalizada, o que me causou enorme estranheza por não saber, ao certo, a minha própria lotação: fui automaticamente credenciado junto ao PPGA e estava oficialmente lotado no Instituto de Filosofia e Ciências Humanas (IFCH), de acordo com o meu contracheque, mas seria de bom tom que eu ministrasse disciplinas na graduação em Ciências Sociais, o que me filiava à Faculdade de Ciências Sociais (FACS).

Fui recebido de forma bastante calorosa e amigável por todos/as os/as colegas do Programa, coordenado naquele momento pelas Profas. Denise Pahl Schaan e Rosa Acevedo Marín, duas pesquisadoras renomadas e muito experientes que teriam, nos anos seguintes, um lugar de destaque em minhas atividades junto ao Programa, além de Agenor Sarraf Pacheco, Cristina Donza Cancela, Flávio Bezerra Barros, Hilton Pereira da Silva, Jane Beltrão e Márcia Bezerra. Os/As demais colegas do Programa, que fui conhecendo aos poucos, sempre se mostraram grandes parceiros, como Diogo Menezes Costa (recém-contratado àquela altura) e Edna Ferreira Alencar. Alguns/mas colegas que pertenciam ao Programa naquele momento já não estão mais, como os geneticistas Sidney Batista dos Santos e Ândrea Ribeiro dos Santos (com os quais mantive, até 2016, um diálogo bastante sistematizado sobre as últimas novidades da genética), o linguista Abdelhak Razki (com quem iniciei um debate prolífico sobre linguagem e cultura), o filósofo Ernani Pinheiro Chaves (com o qual revisei meus conhecimentos e aprendi mais ainda sobre a obra de Michel Foucault, mas também Friedrich Nieztsche e Walter Benjamin) e Flávio Leonel Abreu da Silveira (um parceiro de sempre nos estudos de patrimônio e urbanidade, mesmo trabalhando no Programa de Pós-Graduação em Sociologia e Antropologia). Outros/as muitos docentes integrariam o PPGA nos anos seguintes, em função de novas contratações ou de outras situações (Beatriz de Almeida Matos, Júlia Otero dos Santos, Katiane Silva, Nayara da Silva Camargo, Pedro José Tótora da Glória, Renata de Godoy e Tiago Ferreira Tomé), distribuídos nas mais diversas áreas e campos do conhecimento antropológico (etnologia indígena, arqueologia histórica, arqueologia pública e/ou contemporânea, bioarqueologia, linguística antropológica, etc). O Programa teve também uma perda inestimável, com o falecimento precoce da Prof ${ }^{a}$ Denise Pahl Schaan - e eu perdi, além de uma colega, uma amiga e parceira de pesquisa, coautora de um artigo (GONTIJO; SCHAAN, 2017).

Não demorou muito para perceber, com os meus e as minhas novos/as colegas, que eu era visto como alguém que tinha acumulado uma experiência positiva na gestão da pósgraduação e interessado em estreitar cada vez mais os laços entre os four fields da antropologia, na perspectiva de Franz Boas. Em janeiro de 2014, eu já era içado, assim, ao cargo de vicecoordenador do Programa, tendo a Prof ${ }^{a}$ Denise Pahl Schaan como coordenadora (Portaria 108/2014-Reitoria-UFPA). Em setembro do mesmo ano, Denise resolveu deixar a coordenação e eu tive que assumir interinamente até a nova eleição, realizada no mês seguinte. Fui escolhido para coordenar o Programa até abril de 2016, tendo o Prof. Diogo Menezes Costa, arqueólogo histórico, como vice-coordenador (Portarias 4.380/2014 e 4.310/2015-Reitoria-UFPA). Depois, de abril de 2016 a março de 2018, invertemos e ele passou a ser o coordenador e eu, vicecoordenador (Portaria 478/ 2016-Reitoria-UFPA). Enfim, em abril de 2018, o Prof. Hilton Pereira da Silva, bioantropólogo, foi escolhido para coordenar o Programa, tendo o Prof. Diogo Menezes Costa como vice-coordenador. 
Em março de 2019, o Prof. Diogo preferiu se retirar da vice-coordenação e eu fui novamente conduzido a esse cargo, que ocupo até os dias de hoje, novembro de 2019. Ou seja, entre 2014 e 2019, só não estive na coordenação do PPGA durante alguns meses (entre abril de 2018 e março de 2019). A tarefa não é necessariamente prazerosa, mas contém momentos de júbilo, como por exemplo, quando conseguimos elevar a nota do Programa de 4 para 5 na avaliação quadrienal da CAPES referente a 2013-2016, graças a um grande esforço coletivo de todos/as os/as docentes, discentes e do técnico-administrativo do Programa. Momentos difíceis vêm sendo aqueles de reduções orçamentárias drásticas, que têm como consequência o corte de verbas dedicadas à pesquisa de campo e à participação em eventos de discentes e até mesmo o congelamento (ou a suspensão) de bolsas de mestrado e doutorado, o que torna a tarefa de coordenação bem menos prazerosa.

Muitos desafios foram colocados ao longo desses seis anos passados na UFPA, para além daqueles de cunho administrativo à frente do Programa. Esses desafios é que estão sendo chamados aqui de práticas transformativas - ou seja, aquilo que vem consolidando as experiências performativas anteriores sob a forma de práticas transformativas. Como a pesquisa sempre foi, para mim, a base do fazer(-se) docente na universidade, tive que modificar um pouco a pesquisa que estava em sua etapa final no Piauí para adequá-la às realidades interioranas paraenses: na Amazônia, tratava-se obviamente de dar atenção ao marcador étnico na composição das formas de pertencimento, mas também de pensar no modo como o ambiente ou as paisagens (ou a cultura material socioambiental, como se diz em arqueologia) insinuavam relações sociais bem particulares no que diz respeito às experiências da diversidade sexual e de gênero. O projeto de pesquisa passou a ser intitulado Preenchendo Lacunas: as experiências da diversidade sexual e de gênero em contextos rurais e interioranos e em situações etnicamente diferenciadas na Amazônia e no Nordeste do Brasil, contando com recursos da Chamada MCTI/CNPq/MEC/CAPES n ${ }^{\circ}$ 43/2013 entre 2013 e 2015 - o título do projeto dessa Chamada foi As Experiências da Diversidade Sexual e de Gênero em Contextos Interioranos, Rurais e Etnicamente Diferenciados no Pará - e com a Bolsa de Produtividade em Pesquisa do CNPq até 2019.

A pesquisa foi realizada em diversas localidades do interior do Pará, como Altamira, Breves e Barcarena, mas principalmente em Santarém. Desde 2013, venho frequentando a região de Santarém, graças a uma rede de jovens pesquisadores/as que muito contribuíram com a pesquisa. Em setembro de 2013, a convite da Prof ${ }^{a}$ Carla Ramos, que havia sido minha aluna no IFCS/UFRJ em 2001/2002, atualmente docente do curso de Antropologia e Arqueologia da Universidade Federal do Oeste do Pará (UFOPA), visitei a instituição santarena e conversei com mais ou menos vinte estudantes e técnicos-administrativos interessados/as em pesquisar temas relativos à sexualidade ou ao gênero. Carla me contou que havia uma escassez de pesquisas sobre as temáticas na UFOPA.

Em 2015, enquanto realizava as primeiras etapas da etnografia nessa região, ministrei uma disciplina para o curso de graduação em Antropologia e Arqueologia da UFOPA. Esse curso serviu de "formação" para instigar as pesquisas por parte de estudantes de graduação. A partir desse momento, uma extensão do grupo de pesquisa SEXGEN por mim liderado passou a funcionar também na UFOPA. Estudantes da instituição se integraram à minha pesquisa, alguns deles levando a temática para os estudos pós-graduados (na UFPB, na UnB e na UFRJ, mas também no PPGA/UFPA). Em seguida, em diversas ocasiões, participei de atividades na UFOPA, orientei trabalhos de iniciações científica de estudantes daquela universidade e recebi, em Belém, três estudantes em mobilidade acadêmica para estágios de pesquisa. Alguns artigos e capítulos de livros foram publicados com alguns dos principais resultados da pesquisa até agora sistematizados, principalmente tendo como campo a região de Santarém (FERNANDES; GONTIJO, 2016; FERNANDES, GONTIJO, TOTA; LOPES, 2016a, 2016b; GONTIJO, 2017a, 2017c, 2018c; GONTIJO, DOMINGUES; ERICK, 2016a; GONTIJO, DOMINGUES; ERICK, 2016b; GONTIJO; ERICK, 2016; GONTIJO; ERICK, 2017; GONTIJO; FERNANDES, 2017; GONTIJO, FERNANDES, TOTA; LOPES, 2016). 
Nota-se, na minha produção recente, uma grande quantidade de publicações em parceria com Estêvão Fernandes, um docente da Universidade Federal de Rondônia com quem venho desenvolvendo reflexões de cunho epistemológico e teórico amparadas pela perspectiva póscolonial. Com ele, acabamos formando uma espécie de pequena rede de pesquisadores/as, geralmente vinculados/as a instituições das regiões Norte, Nordeste e Centro-Oeste. A rede reúne pessoas interessadas em compreender a persistência de algumas lacunas nos estudos sobre a diversidade sexual e de gênero no Brasil, com o intuito de preencher essas lacunas. Alguns dossiês foram organizados em periódicos nacionais (e um está em andamento), com certo grau de pioneirismo, por exemplo, na abordagem de temas até então pouco tratados pelos estudos sobre a diversidade sexual e de gênero, tais como as experiências em contextos rurais e interioranos, em situações etnicamente diferenciadas (indígenas e quilombolas) e em conjunturas de imigração.

Outro desafio a ser enfrentado veio com as disciplinas que eu iria ministrar na nova instituição. Não contente com as disciplinas ministradas no curso de graduação em Ciências Sociais entre 2013 e 2014 (Antropologia Econômica e Sociologia da Infância e Adolescência eram as disciplinas que "sobravam" para mim e que pouco valorizavam o potencial que eu podia oferecer), fui levado a ministrar disciplinas no curso de graduação em Cinema, no Campus de Belém e, sobretudo, no curso de graduação em Etnodesenvolvimento. Como já dissemos em um artigo, publicado em 2017 (GONTIJO, 2017c, p.58):

Em Altamira, às margens do Rio Xingu, no momento em que as obras de construção da gigante Usina Hidrelétrica de Belo Monte acentuavam seus impactos devastadores sobre os povos e populações da região, foi criado um curso de graduação em Etnodesenvolvimento, vinculado à Faculdade de Etnodiversidade (juntamente com o curso de Educação do Campo), no campus local da Universidade Federal do Pará, baseado nos preceitos da educação diferenciada e da pedagogia da alternância. O curso é voltado para atender a uma demanda antiga oriunda dos povos e populações impactados negativamente, não somente pelas obras mais recentes de Belo Monte, mas também de outros megaempreendimentos desenvolvimentistas no estado, por ações ilegais de grileiros e fazendeiros do agronegócio ou pecuaristas, por invasões de seus territórios tradicionais pelo crescimento desmesurado das cidades, pelo empobrecimento ligado à degradação ambiental causada pela industrialização e pelo avanço avassalador do capital financeiro e da consequente especulação fundiária, pela vulnerabilização social gerada por políticas insensíveis às realidades locais rurais e interioranas amazônicas, etc.

O curso é voltado exclusivamente para estudantes indígenas, quilombolas, ribeirinhos, extrativistas, pescadores, pequenos agricultores, sindicalistas rurais, agentes dos movimentos sociais urbanos (como os movimentos negros), dentre outras categorias, que ingressam, através de um processo seletivo especial, com o objetivo de produzir conhecimentos que debatam as questões e interesses locais com os ideais empresariais e governamentais de crescimento econômico e, a partir daí, sejam constituídas formas mais sustentáveis e menos impactantes de desenvolvimento (etnodesenvolvimento).

As disciplinas ministradas nesse curso, entre 2015 e 2018, foram Nação e Nacionalidade, Antropologia e Diferença e, principalmente, Gênero, Raça/Etnicidade e Sexualidade. Essa última, ministrada em três ocasiões - duas em Altamira e uma em Soure, na turma que foi iniciada naquele campus do Arquipélago do Marajó em 2018 - contribuiu para que eu aprofundasse, junto aos/às discentes, as questões que eu vinha levantando em minhas pesquisas, voltadas para as experiências da diversidade sexual e de gênero no contexto interiorano e em situações etnicamente diferenciadas na Amazônia. Afinal, esses/as discentes eram todos, com raras exceções, moradores de áreas rurais ou interioranas e/ou membros de comunidades tradicionais. Eu estava diante de informantes privilegiados/as que muito me ensinaram, não somente sobre o meu objeto de pesquisa, mas sobre a vida na Amazônia, essa vida tão intimamente relacionada às águas abundantes e aos seus territórios ribeirinhos.

EntreRios - Revista do PPGANT -UFPI -Teresina •Vol. 3, n. 1 (2020) 
No PPGA, fui honrado com as disciplinas de História do Pensamento Antropológico e Teoria Antropológica Contemporânea, ambas obrigatórias, que venho ministrando praticamente todos os anos - a primeira, um verdadeiro desafio por ter como objetivo a história da antropologia nos quatro movimentos que a compõem, a saber antropologia social, arqueologia, bioantropologia e antropologia linguística; a segunda, um outro verdadeiro desafio por também demandar conhecimentos bem atualizados nos four fields.

Além dessas, venho ministrando disciplinas de Leituras que muito contribuem para organizar as reflexões acerca dos meus novos interesses de pesquisa: por exemplo, a partir de um artigo publicado juntamente com a Prof ${ }^{a}$ Denise Pahl Schaan em 2017 (GONTIJO; SCHAAN, 2017) e logo após a sua morte em 2018, com o intuito de sensibilizar estudantes do PPGA e de outros cursos para a necessidade de se pensar a diversidade sexual e gênero a partir dos four fields, ministrei Leituras em Antropologia Social, Arqueologia e Bioantropologia/Bioarqueologia: gênero, sexualidade e corporalidades. Já em 2019, foi a vez de ministrar Leituras em Antropologia Social, Arqueologia, Bioantropologia e Antropologia Linguística: Diversidade Sexual e de Gênero, Discursividade e Nação para raciocinar sobre as relações entre a ideologia de construção de nação (nation-building) e os nacionalismos e os dispositivos de sexualidade (em contextos principalmente não brasileiros), a partir de minhas novas pesquisas (GONTIJO, 2018a; 2018b; FERNANDES; GONTIJO, 2019).

Outra experiência de docência bastante desafiadora, além daquela da graduação em Etnodesenvolvimento, foi a turma de Doutorado criada no campus da UFPA em Breves, município mais populoso do Arquipélago do Marajó. Graças à brilhante iniciativa do Prof. Agenor Sarraf-Pacheco, um historiador afeito aos estudos culturais e à perspectiva pós-colonial latino-americana, o PPGA ofertou uma única turma de doutorado para mestres da região sul do Arquipélago de Marajó, no âmbito de um dos muitos programas institucionais da UFPA, o Programa de Apoio à Qualificação de Docentes e Técnicos (PADT).

Breves encontra-se a doze horas de barco de Belém, não havendo outro meio de se chegar lá. O edital foi lançado na primeira metade de 2014 e as atividades com a turma dos/as oito discentes selecionados/as (dentre os/as quais, quatro docentes do campus da UFPA em Breves) começou na segunda metade do mesmo ano. As disciplinas eram ministradas no campus de Breves de forma blocada, as orientações aconteciam no momento em que as disciplinas eram ministradas, os/as discentes participavam de eventos no campus de Belém e eventos eram organizados também no campus de Breves, contando com a participação de docentes e discentes do PPGA de Belém e de convidados/as externos/as. As teses foram defendidas em 2018, tratando dos mais variados temas antropológicos, tais como as experiências sexuais e as relações de gênero entre mulheres ribeirinhas e homens embarcados em navios que transitam nos rios que dão acesso ao Amazonas, as consequências e impactos sociais de programas governamentais junto a comunidades ribeirinhas, a educação diferenciada na região, o atendimento em serviço social prestado a mulheres idosas pela Prefeitura de Breves, as encantarias e sistemas mágico-religiosos de comunidades ribeirinhas, as concepções das populações locais sobre o material coletado em prospecções arqueológicas à beira de um dos rios da região, dentre outros temas de grande relevância para a compreensão dos modos de vida locais e para a revisão de políticas públicas voltadas para a região. Dos quatro discentes que não eram docentes da UFPA, três já o são atualmente, graças ao doutoramento.

Essa experiência, juntamente com aquela do curso de Etnodesenvolvimento, tornaramme mais amazônida, fazendo-me entender que a Amazônia era não somente múltipla e diversificada, mas que era preciso rever as nossas lógicas de ensino, ampliar os nossos horizontes metodológicos e romper com nossas fronteiras acadêmicas para pensar a universidade de forma mais dinâmica e itinerante, com práticas mais sistemáticas e criativas de interação com os interiores do Brasil. Em Breves, aproveitei também, ao longo das semanas passadas para ministrar disciplinas e orientar, para realizar pesquisas de campo etnográficas, 
gerando dados bem interessantes que seriam posteriormente comparados com aqueles obtidos em Santarém e em Altamira (esses dados estão sendo tratados e não há publicações especificamente sobre Breves).

No PPGA, orientei até o presente momento dez dissertações de mestrado (sete já concluídas e três em andamento) e sete teses de doutorado (quatro já concluídas e três em andamento) e coorientei três dissertações de mestrado (todas já concluídas) e duas teses de doutorado (uma concluída e uma em andamento). Sem perceber, tornei-me o docente com o maior número de orientações concluídas no Programa. Vale ressaltar que algumas dessas dissertações e teses orientadas se inseriam ou se inserem nesse diálogo bastante fértil, já longamente citado acima, corriqueiro no PPGA, entre as áreas de concentração ou four fields: atualmente, oriento uma tese em arqueologia e já coorientei duas dissertações na mesma área, além da supervisão de um pós-doutorado em antropologia linguística.

Essas dissertações e teses trataram de assuntos bastante diversificados, tais como: as experiências da lesbianidade em Belém; o movimento de gays, lésbicas, bissexuais e transexuais/transgêneres no Pará; a cultura material associada às experiências da diversidade sexual e de gênero; a frequência de pessoas homossexuais a igrejas neopentecostais; as sociabilidades ribeirinhas e as moralidades relacionadas às sexualidades no Marajó; as encantarias e sistemas mágico-religiosos ribeirinhos como formas patrimoniais; as sensorialidades e as sociabilidades em mercados e feiras de Belém; as percepções de paisagens em videoclipes produzidos em ou sobre a Amazônia; as narrativas audiovisuais em documentários realizados em Santarém; as trajetórias de mulheres artistas plásticas paraenses e seu apagamento ou silenciamento pela história oficial das artes na Amazônia; as vivências de mulheres torcedoras e a cena do futebol feminino no Brasil; os impactos ou efeitos culturais dos megaprojetos de desenvolvimento de mineração no Pará; as concepções de trabalhadores em escavações arqueológicas históricas sobre o material coletado; a organização social de mulheres grafiteiras em Belém; o funcionamento de pontos de memória e museus comunitários em bairros periferizados da capital paraense; a cultura material de habitações construídas por imigrantes japoneses no interior do Pará; as vivências de peconheiros, extrativistas do açaí; dentro outros.

Desde 2014, venho ainda orientando sistematicamente discentes de graduação em Ciências Sociais ou em Direito (ou em Antropologia e Arqueologia, no caso de um discente da UFOPA), no âmbito do Programa de Iniciação Científica, discentes que têm contribuído significativamente com as minhas pesquisas em contextos interioranos e em situações etnicamente diferenciadas. Além das orientações, tive a oportunidade de supervisionar, em 2017, uma linguista recém-doutora, bolsista do Programa Nacional de Pós-Doutorado (PNPD) da CAPES, Nayara Camargo, que desenvolveu uma interessante pesquisa na área de antropologia linguística junto ao povo Tapayuna, habitante do Parque Indígena do Xingu. Após o estágio de pós-doutorado, Nayara foi aprovada em concurso público para a carreira do magistério superior e exerce suas funções na Universidade Federal do Sul e Sudeste do Pará (UNIFESSPA). Supervisionei também, entre 2016 e 2018, na outra ponta da carreira acadêmica, uma bolsista do Programa de Professor/a Visitante Sênior (PVS) da CAPES e da Fundação Amazônia de Amparo a Estudos e Pesquisa do Pará (FAPESPA), Eliane Cantarino O'Dwyer, grande pesquisadora vinculada à Universidade Federal Fluminense. A pesquisadora desenvolveu um estudo bastante amplo intitulado Etnicidades, Práticas Culturais e Formas de Organização Social em um Contexto Regional do Baixo Amazonas, envolvendo docentes e discentes da UFPA e da UFF. Claro que, nesse segundo caso, a minha supervisão foi meramente formal, já que aprendi muito - e ainda venho aprendendo - no convívio frequente com a Prof ${ }^{a}$ Eliane em suas atividades junto ao PPGA. 
Na UFPA, participei de inúmeras comissões, assim como havia feito na UFPI, mas dessa vez, com a experiência acumulada lá. E como não poderia deixar de ser, com a marca do PPGA, participei de comissões envolvendo colegas e interesses de todas as áreas dos four fields, como bancas examinadoras de concurso público para docente de arqueologia em duas ocasiões (2016 e 2019), comitês de avaliações diversas e de projetos e grupos de organização de eventos. Além de participar de inúmeros eventos científicos no Brasil e no exterior - coordenando grupos de trabalho, proferindo palestras e conferências e apresentando comunicações em mesas redondas -, colaborei na organização de alguns eventos, dentre os quais o Seminário Internacional Antropologia em Foco, evento do PPGA, nas edições de 2014 (juntamente com a Prof ${ }^{\text {a }}$ Rosa Acevedo Marín, com recursos da CAPES) e 2017 (juntamente com os Profs. Diogo Menezes Costa, arqueólogo, e Flávio Bezerra Barros, bioantropólogo, também com recursos da CAPES) e de outros eventos menores.

Enfim, uma guinada seria dada, a partir de 2018/2019, com um novo projeto de pesquisa, intitulado Diversidade Sexual e de Gênero, Ideologia de Nation-Building e Antropologia, agora voltado para a compreensão da maneira como as ideologias de construção de nação e os nacionalismos trataram (ou não) a diversidade sexual e de gênero nos mais variados contextos nacionais (inclusive, em menor grau, no Brasil), projeto que conta também com Bolsa de Produtividade em Pesquisa do CNPq e que já gerou publicação (GONTIJO, 2018a). Nas pesquisas que eu havia realizado até aqui, principalmente ao longo da década de 2010, percebese que os silenciamentos, apagamentos e ou enquadramentos reguladores da diversidade sexual e de gênero parecem ser mecanismos inseridos em um dispositivo essencializador e naturalizador - sustentado por sistemas de pensamento e de ação/intervenção médicocientífico e jurídico-normativo - de produção do projeto hegemônico de nação no Brasil - uma nacionalidade eurocentrada, branca, heteronormativa e reprodutora de colonialismos internos. Agora, trata-se, nesse novo projeto, (1) de abordar essas tecnologias de silenciamentos, apagamentos e/ou enquadramentos reguladores da diversidade sexual e de gênero, num âmbito mais amplo, (2) no seio dos processos de construção e manutenção de identidades nacionais ou "ideologias de nation-building" em conjunturas atuais de sociedades plurais pelo mundo afora, (3) numa perspectiva comparada, multissituada ou global (4) consciente dos efeitos múltiplos da colonialidade do saber e do poder e das novas situações coloniais (5) e verificar a relação da antropologia (e também da arqueologia) com esses mecanismos no seio desses processos (BURAWOY, 2000; CARDOSO DE OLIVEIRA, 1993; LANDER, 2005; MARCUS, 1991; McCLINTOCK, 1993; McGUIRE, 2008; PEIRANO, 1992). Esse projeto foi a forma que encontrei de unir o meu forte interesse "mochileiro" por viagens (ao longo da década de 2010, muitos mais países foram percorridos), a paixão pela antropologia (em todos os seus campos ou fields) e a vontade incessante de transformar o mundo (ou, pelo menos, contribuir para apaziguar a indignação oriunda da opressão muitas vezes gerada pela produção de arbitrários culturais e minimizar os efeitos perversos de certas formas de relações de poder).

Esse projeto não teria sido possível sem a convivência com os/as colegas do PPGA: de Agenor Sarraf-Pacheco, veio-me a inspiração para refletir sobre a situação colonial e a colonialidade, assim como das conversas com Rosa Acevedo Marín, com a qual aprofundei as leituras sobre as relações de poder, os conflitos e as formas de resistência; o tema do poder também foi muito tratado em minhas discussões com o filósofo especialista do pensamento de Michel Foucault, Ernani Pinheiro Chaves; nação, nacionalismo e ideologias de nation-building eram os temas privilegiados nos diálogos com Eliane Cantarino O'Dwyer, Professora Visitante Sênior do Programa; somou-se o interesse pela situação dos povos e comunidades tradicionais, indígenas e quilombolas em particular, na maneira como são tratados pelo Estado nacional e como formulam percepções de nação como formas de resistência, a partir de conversas com Jane Beltrão, Rosa Acevedo Marín, Eliane Cantarino O'Dwyer, Katiane Silva, Júlia Otero dos Santos e Flávio Bezerra Barros; com os / as colegas da área de arqueologia, Márcia Bezerra e Diogo Mene- 
-zes Costa, e da museologia (Márcia Bezerra trabalha no curso de graduação em museologia, assim como outros colegas que passaram rapidamente pelo PPGA, como Hugo Menezes Neto), percebia cada vez mais o quanto as produções arqueológicas e antropológicas e as políticas do patrimônio tinham servido e ainda serviam para legitimar os discursos nacionais em muitos contextos e que isso era visível, por exemplo, na constituição das coleções museológicas, em particular nos museus e galerias nacionais, e na construção de monumentos representativos da nação; dialogando com os/as colegas da bioantropologia, da bioarqueologia e da genética, como Hilton Pereira da Silva, encontrei informações preciosas sobre a consolidação do sistema médico-científico como único provedor de verdades sobre os corpos, conformando o dispositivo de sexualidade, de que falava Michel Foucault, e sobre a invenção e a naturalização dos critérios definidores do dimorfismo sexual e do binarismo de gênero (a leitura das bioantropólogas e bioarqueólogas feministas foi de fundamental importância para a crítica do sistema médicocientífico); em 2017, supervisionei um estágio de pós-doutorado na área de antropologia linguística, através do Programa Nacional de Pós-Doutorado (PNPD), já citado acima, o que me permitiu reforçar os conhecimentos sobre discursos e discursividades e trazê-los para o contexto da elaboração de ideologias de nation-building; enfim, o contato mais intenso com discentes estrangeiros/as, sobretudo latino-americanos (inclusive, sob a minha orientação), ajudaram-me a perceber processos curiosos de elaboração de discursos nacionais e as tecnologias de manutenção da situação colonial. Juntando as questões relativas ao poder e aos conflitos na constituição de ideologias de nation-building com os discursos científicos legitimadores e/ou produtores dessas ideologias, inclusive aqueles relativos às verdades dos "bons corpos" e das "boas mentes" (ciências biomédicas e ciências jurídico-morais), cheguei à ideia da governamentalidade (baseada na gestão do território, da população e da segurança), também abordada por Michel Foucault, e à reflexão sobre o modo como as nações (e/ou os Estados nacionais) se mantêm em função da colonialidade do saber e do poder.

Ora, vejo-me, assim, não mais "flertando" com a ciência política, nem "namorando" com a sociologia e, sem desfazer o "casamento" com a antropologia, estaria agora experimentando um "relacionamento pan-amoroso" ou uma forma prazerosa de poliamor envolvendo todas essas áreas, às quais se somam a arqueologia, a bioantropologia e a antropologia linguística. Essa era, de fato, a minha nova "casa" (com aspas) - ou seja, partir dos campos da antropologia e das ciências sociais para compreender os seus impactos na conformação de discursos nacionais que enquadram a diversidade sexual e de gênero -, proporcionada pela minha nova casa (sem aspas) - ou seja, os diálogos promovidos a partir do PPGA.

\section{Considerações Finais? Perspectivas...}

No início da tarde de 29 de outubro de 2018, fui surpreendido com um e-mail enviado por Michèle Pagès:

Bonjour Fabiano, j'espère que vous vous souvenez de votre directrice de mémoire de recherche en Maîtrise de Sociologie à Aix. Je suis à la retraite depuis l'année dernière mais je pense toujours à mes anciens étudiants. Vous aviez réalisé un mémoire très intéressant sur les apparences des homosexuels à la plage et j'ai suivi un peu votre carrière universitaire et votre retour au Brésil.

Comme vous êtes le seul brésilien que je connais, je ne peux pas manquer d'avoir une pensée pour vous aujourd'hui, vous comprendrez aisément pourquoi. Je vous envoie donc mes salutations confraternelles de La Ciotat où je réside.

J'espère avoir de vos nouvelles.

Bien cordialement. 


\section{Michèle Pagès ${ }^{12}$}

Eu não tinha notícias daquela que tinha sido a minha orientadora de trabalho de conclusão de curso na graduação em Sociologia, na França, desde que terminei a graduação, ou seja, desde 1995, há 24 anos atrás. O e-mail chegava no dia seguinte às eleições presidenciais de 2018: o balde d'água fria que parecia não mais parar de se despejar sobre a minha cabeça desde a véspera se juntava, nesse momento, a um rio de lágrimas que copiosamente não consegui conter. A Amazônia nunca tinha sido tão aquosa... Imediatamente, pus-me a responder à minha primeira orientadora, tão querida, que, com as suas palavras, trazia-me um enorme reconforto com um toque de esperança de que ninguém mais estaria sozinho no mundo, nesse novo velho mundo de tantas atrocidades inomináveis, mas também de tantas resistências criativas.

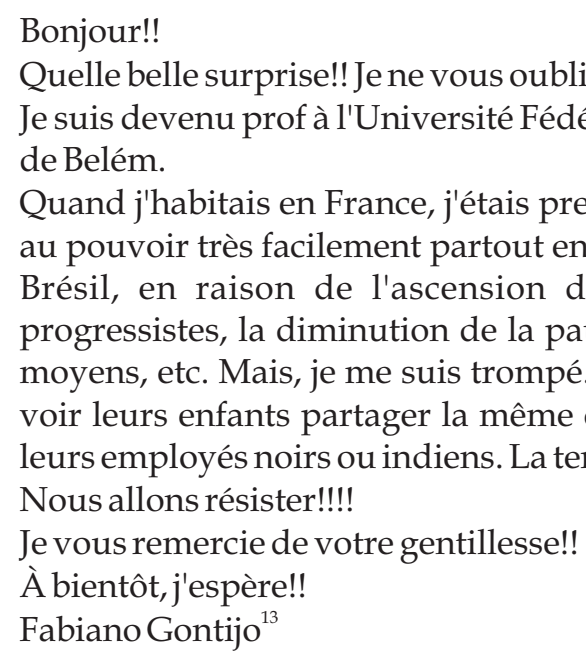

Talvez a minha apresentação do que aconteceu nos últimos 24 anos no Brasil tenha sido demasiadamente resumida e a interpretação sociológica formulada para subsidiar uma compreensão do que estava acontecendo, bastante simples. Tenho consciência disso. Era o que eu conseguia escrever naquele momento. Michèle respondeu novamente, agora com uma interessantíssima análise da situação política na França e na Itália; os medos que alimentam a classe média, como aquele relativo ao déclassement social (Michèle sempre foi uma grande adepta das teorias sociais de Bourdieu, como eu também o sou, até certo ponto), e as consequências às vezes paradoxais desses medos; a estrutura quase que universal dos processos históricos de ascensão das múltiplas formas de fascismos; os perigos da resistência, como no Chile pósAllende vivenciados por um ex-aluno; os encarceramentos arbitrários, a censura e a tortura, como havia acontecido com um outro ex-aluno dela, assassinado nos Camarões... Assim, ela me exortava, como uma mãe, a resistir com prudência. Esse cuidado era comum nas relações entre orientandos/as e orientadores/as no Brasil, mas não entre orientandos/as e orientadores/as na França, o que me deixou fortemente emocionado. Essa foi a minha primeira orientação, de fato.

10 Tradução livre do francês: "Bom dia, Fabiano. Espero que você se lembre de sua orientadora de trabalho de conclusão de curso de sociologia em Aix. Estou aposentada desde o ano passado, mas penso sempre em meus antigos estudantes. Você tinha realizado um trabalho de conclusão de curso muito interessante sobre as aparências dos homossexuais na praia e eu acompanhei um pouco a sua carreira universitária e o seu retorno ao Brasil. Como você é o único brasileiro que conheço, não posso deixar de pensar em você hoje, você entenderá perfeitamente o porquê. Envio as minhas saudações de confraternização de La Ciotat, onde resido. Espero obter notícias suas. Bem cordialmente."

11 Tradução livre do francês: “Bom dia!! Que boa surpresa!! Nunca me esquecerei de você!! Tornei-me professor da Universidade Federal do Pará, na Amazônia brasileira, na cidade de Belém. Quando morava na França, tinha quase certeza de que a extrema-direita chegaria um dia ao poder com muita facilidade por toda parte na Europa. Acreditava que isso nunca aconteceria no Brasil, em razão da ascensão da esquerda, os benefícios dos governos progressistas, a diminuição da pobreza e da fome, o aumento das rendas médias, etc. Mas eu me enganei. Para as camadas médias, é insuportável ver seus filhos compartilhando uma mesma turma na universidade pública com os filhos dos seus empregados negros ou indígenas. O terror está se instalando... Nós resistiremos!!!! Agradeço por sua gentileza!! Até breve, espero!!" 
Na França, trabalhei em restaurantes como plongeur (lavando a louça) durante cinco anos para financiar os meus estudos, com a ajuda de meu companheiro. Depois, pelo fato de minha dissertação de mestrado ter obtido a premiação máxima, fui contemplado com um contrato de allocataire de recherche, o equivalente, no Brasil, a uma bolsa de assistente de pesquisa com a duração de três anos, com a possibilidade de renovação por mais um ano. Essa era a bolsa de doutorado na França, um contrato de trabalho, um contrat de travail à durée déterminée. Por sorte, $\mathrm{o}$ meu orientador, Michel Agier, estava sempre muito ocupado com as suas pesquisas em África, no Brasil e na Colômbia e quase não me pedia para ajuda-lo, o que me deixava bastante livre para desenvolver a tese. O pagador era o Rectorat de Paris, vinculado ao Ministério francês da Educação. Dinheiro público, instituição pública e gratuita de ensino superior.

Ao voltar para o Brasil, optei por ser bolsista do CNPq, Programa Especial de Estímulo à Fixação de Doutores (PROFIX, antes chamada de "Recém-Doutor"), para desenvolver atividades no IFCS/UFRJ. Dinheiro público, instituição pública e gratuita de ensino superior.

A partir de 2002, integrei-me a uma instituição pública e gratuita de ensino superior como docente. Ao longo das décadas de 2000 e 2010, vi como um governo preocupado com as questões sociais é capaz de atuar nas instituições de educação públicas e gratuitas, incrementando o alcance do ensino, a qualidade da pesquisa, o impacto social da extensão e a excelência da inovação. Agora, eu participava da produção de uma universidade cada vez mais inclusiva e presente na vida de cada pessoa, capacitada para a promoção da cidadania social e o respeito à diversidade cultural. Na UFPA, os esforços múltiplos de todos/as desembocaram numa das universidades com a maior proporção de estudantes (e também de docentes) negros, indígenas, quilombolas, portadores de necessidades especiais e carentes, em grande parte graças aos programas de ações afirmativas. Muitos/as estudantes são bolsistas de variadas modalidades (bolsa-permanência, bolsas de mestrado e doutorado, bolsas de iniciação científica, bolsas de iniciação à docência, bolsas de extensão, etc). As pesquisas e os programas de extensão de qualidade ajudam na promoção de um mundo melhor, uma sociedade mais justa, um planeta mais sustentável e uma nova organização das relações globais. Dinheiro público, instituição pública e gratuita de ensino superior.

O dinheiro público, dinheiro da "casa" para a qual trabalho, constrói casas que reforçam "casas" melhores. Não encaro esse memorial como o relato finalizado de uma carreira. Mas, vejo esse exercício como mais uma atividade de produção que tem por objetivo refletir sobre como ajustar melhor "casas" a casas, precisamente num momento em que as "casas" estão sendo colocadas pelo avesso e as casas são encaradas como inimigas das "casas", quando, de fato, deveria ser o contrário. "Existirmos: a que será que se destina?", perguntava-se Caetano Veloso, ao homenagear o amigo piauiense Torquato Neto. Eu responderia: resistirmos, a isso se destina a existência nesse momento, como uma forma de ajustar "casas" a casas.

\section{Referências bibliográficas:}

AUGÉ, Marc, Não-Lugares : Introdução a uma antropologia da super-modernidade, Campinas, Papirus, 1994.

ÁVILA, Maria Betânia; PORTELLA, Ana Paula; FERREIRA, Verônica (orgs.). Novas Legalidadese Democratização da Vida Social: família, sexualidade e aborto. Rio de Janeiro: Garamond, 2005.

BARTH, Fredrik. "A Análise da Cultura nas Sociedades Complexas". In: O Guru, o Iniciador e Outras Variações Antropológicas. Rio de Janeiro: Contra Capa, 2000. pp. 108-138.

BENSA, Alban. La Fin de l'Exotisme: Essais d'anthropologie critique. Toulouse: Anacharsis, 2006. 
BERTAUX, Daniel. Le Récit de Vie. Paris: Armand Collin, 2005.

BOURDIEU, Pierre. A ilusão biográfica. In: Razões Práticas. Campinas: Papirus, 1996 . La Distinction. Paris : Minuit, 1979.

BRAH, Avtar. Diferença, Diversidade, Diferenciação. In: Cadernos Pagu,n. 26, 2006.

BURAWOY, Michael, et al. (orgs.). Global Ethnography: forces, connections, and imaginations in a postmodern world. Berkely: University of California Press, 2000.

BUTLER, Judith. Problemas de Gênero: feminismo e subversão da identidade. Rio de Janeiro: Civilização Brasileira, 2003.

CARDOSO DE OLIVEIRA, Roberto. “O Movimento dos Conceitos na Antropologia”. Revista de Antropologia, 36, 1993:13-31.

CARRARA, Sérgio; SIMÕES, Júlio. “Sexualidade, Cultura e Política: a trajetória da identidade homossexual masculina na antropologia brasileira". Cadernos Pagu, 28, 2007: 65-99.

CAVALCANTI, Maria Laura Viveiros de Castro. Carnaval Carioca: Dos bastidores ao desfile, Rio de Janeiro: UFRJ, 1994.

CONSTANT, Paule. Un Monde àl'Usage des Demoiselles. Paris: Gallimard, 1987.

Da MATTA, Roberto. Carnavais, Malandros e Heróis: Para uma sociologia do dilema brasileiro. Rio de Janeiro: Zahar, 1978.

ENEIDA (DE MORAIS). História do Carnaval Carioca. Rio de Janeiro: Civilização Brasileira, 1958.

FERNANDES, Estêvão; GONTIJO, Fabiano. "Como Ser um Queer Não Enquadrado: axialidades radicais para tempos obscurantistas". Revista de Arqueologia Pública, 13 (1), 2019: 6684.

“Diversidade Sexual e de Gênero e Novos Descentramentos: um Manifesto Queer Caboclo". Amazônica: Revista de Antropologia, 8 (1), 2016: 14-22.

FERNANDES, Estêvão; GONTIJO, Fabiano; TOTA, Martinho; LOPES, Moisés. “Apresentação”. Amazônica: Revista de Antropologia, 8 (1), 2016a: 9-12.

. “Diversidade Sexual e de Gênero em Áreas Rurais, Contextos Interioranos e/ ou Situações Etnicamente Diferenciadas. Novos Descentramentos em Outras Axialidades Apresentação". ACENO: Revista de Antropologia do Centro-Oeste, 3 (5), 2016b: 10-13.

FEAL, R. "Spanish American Ethnobiography and the Slave Narrative Tradition: 'Biografía de un Cimarrón' y 'Me Llamo Rigoberta Menchú'”. Modern Language Studies, 20 (1), 1990: 100-111. 
FISCHER, Michael. "Ethnicity and the Post-Modern Arts of Memory". In: CLIFFORD, James; MARCUS, Georges E. (orgs.). Writing Culture: the poetics and politics of ethnography. Berkeley / Lons Angeles / Londres: University of California Press, 1986. pp. 194-233.

FRY, Peter. "Homossexualidade Masculina e Cultos Afro-Brasileiros". In: Para Inglês Ver: identidade e política na cultura brasileira. Rio de Janeiro: Zahar, 1982. pp. 54-86.

FRY, Peter; MacRAE, Edward. O Queé Homossexualidade. São Paulo: Brasiliense, 1983.

GEERTZ, Clifford. The Intepretation of Cultures. Nova York: Basic Bookks, 1973.

GOLDENBERG, Mirian. Toda MulheréMeio Leila Diniz. Rio de Janeiro: Record,1996.

GOLDWASSER, Maria Júlia. O Palácio do Samba. Dissertação de Mestrado. Programa de PósGraduação em Antropologia Social, Museu Nacional, Universidade Federal do Rio de Janeiro, 1975.

GONÇALVES, Marco Antônio et al. (orgs.). Etnobiografia - subjetivação e etnografia. Rio de Janeiro: 7 Letras, 2012.

GONTIJO, Fabiano. "Nation-Building, Gênero e Política no Cazaquistão: o caso do Homem Dourado". Mana, 24 (3), 2018a:151-185.

“Biologia, Direito, Perspectiva Queer e Intersexualidade". Teoria Jurídica Contemporânea, 3 (1), 2018b:120-139.

"Intersexualidade, Bioantropologia/Bioarqueologia e Poder: uma Narrativa Biográfica Amazônica”. Bagoas: Revista de Estudos Gays, 12, (18), 2018c: 48-73.

“As Experiências da Diversidade Sexual e de Gênero no Interior da Amazônia: apontamentos para estudos nas Ciências Sociais”. Ciência e Cultura, 69 (1), 2017a: 50-53.

"As Ilhas Trobriand, a Antropologia e os Dimdim: algumas considerações sobre etnografia, turismo e refelxividade em 'lugares sagrados'”. Revista de Antropologia, 60 (1), 2017b: 263-308.

"Gênero, Sexualidade e Etnodesenvolvimento na Amazônia: reflexões a partir de tipos-ideais". Revista FSA, 14 (5), 2017c: 55-72.

"Antropologia Fora dos Eixos? Algumas considerações sobre as particularidades da formação de um campo de pesquisas no Piauí, Brasil”. . Revista FSA, 12 (5), 2015a: 49-62.

"Sexualidade e Ruralidade no Brasil: o que os estudos rurais e os estudos de gênero e sexualidade (não) dizem sobre essa relação?" Vivência, 1 (45), 2015b: 145-158.

“Kátia Tapety: Ora Mulher, Ora Travesti? Gênero, Sexualidade e Identidades em Trânsito no Brasil". Cadernos Pagu, 43, 2014: 299-319. 
. "Diversidade Sexual e de Gênero no Mundo Rural Brasileiro: esboço de reflexões preliminares". Revista FSA, 10 (2), 2013: 84-100.

“Outros Campos, Outros Desejos? Considerações sobre família, amor, gênero e sexualidade no Piauí". Amazônica: Revista de Antropologia, 3 (2), 2011: 268-286.

O Rei Momo e o Arco-Íris: carnaval e homossexualidade no Rio de Janeiro. Rio de Janeiro: Garamond, 2009.

"Quand Momus Passe sous 1'Arc-en-Ciel: la construction sociale des images identitaires homosexuelles dans le carnaval de Rio de Janeiro". Vibrant, 5 (2), 2008a:304-337.

Fabiano. “Identidade Cultural, Ritual e Cidadania: considerações preliminares acerca dos festivais de arte no Piauí". Carta CEPRO, 24 (1), 2008b: 50-53.

. “Amar É... Entre Iguais: representações do amor e da família entre homossexuais identitários teresinenses". In: BARROS Jr., Francisco de O.; LIMA, Solimar O. (orgs.). Homossexualidades sem Fronteiras: olhares sobre o Piauí. Rio de Janeiro: Booklink, 2007.

“Identidades Homossexuais e Discriminação Sexual em Teresina”. In: LIMA, Maria Auxiliadora F.; FROTA, Wander N. (orgs.). Phoros: estudos linguísticos e literários. Rio de Janeiro: Caetés, 2006.pp. 202-216.

“Culturas Diversas, Homossexualidades Plurais, Legalidades Múltiplas". In: ÁVILA, Maria Betânia; PORTELLA, Ana Paula; FERREIRA, Verônica (orgs.). Novas Legalidades e Democratização da Vida Social: família, sexualidade e aborto. Rio de Janeiro: Garamond, 2005a. pp. 121-126.

. “Homossexualidades Periféricas? Resultados de pesquisa sobre a vivência das homossexualidades em Teresina, Piauí". Revista FSA, 2 (2), 2005b:57-69.

. "Rei Momo e o Arco-Íris: etnografia da construção social das imagens identitárias homossexuais através do carnaval do Rio de Janeiro". In: BRANDÃO, Saulo C. S.; LIMA, Maria Auxiliadora F. (orgs.). Ensaios Reunidos: coletânea do Mestrado em Letras - UFPI. Teresina: Halley, 2005c. pp. 15-46.

“ "Imagens Identitárias Homossexuais, Carnaval e Cidadania”. In: RIOS, Luís Felipe; ALMEIDA, Vagner de; PARKER, Richard; PIMENTA, Cristina; TERTO Jr., Veriano (orgs.). Homossexualidade: produção cultural, cidadania e saúde. Rio de Janeiro: ABIA, 2004a. pp. 63-68.

. “Quand Momus Passe sous l'Arc-en-Ciel: la construction sociale des images identitaires homosexuelles dans le carnaval de Rio de Janeiro". Sociétés, 2 (84), 2004b: 65-90.

. “Quem são os Simpatizantes? Culturas identitárias homossexuais no Brasil urbano". Boletim Sexualidade, Gênero e Sociedade (CLAM), XI (21), 2004c: 1-6.

“O Arco-Íris e a Ortodoxia: culturas identitárias homossexuais no Brasil”. In: LOPES, Denilson (org.). Imagens E Diversidade Sexual: estudos da homocultura. São Paulo: Nojosa Edições, 2004d. pp. 453-458. 
. "Carioquice ou Carioquidade? Ensaio etnográfico das imagens identitárias cariocas". In: GOLDENBERG, Mirian (org.). Nu E Vestido: dez antropólogos revelam a cultura do corpo carioca. Rio de Janeiro: Record, 2002.pp. 41-77.

Corps, Apparences et Pratiques Sexuelles: socio-anthropologie des homosexualités sur une plage de Rio de Janeiro. Lille: GKC, 1998.

GONTIJO, Fabiano; COSTA, Francisca Célia. “'Ser Traveco é Melhor que Mulher': considerações preliminares acerca das discursividades do desenvolvimentismo e da heteronormatividade no mundo rural piauiense". Bagoas: Revista de Estudos Gays, 6 (8): 2012:171-186.

GONTIJO, Fabiano; DOMINGUES, Bruno; ERICK, Igor. “'Namoradas ou Dançarinas?' Etnografia das Concepções sobre a Diversidade Sexual e de Gênero de Artesãos de Brinquedos de Miriti no Pará". ACENO: Revista de Antropologia do Centro-Oeste, 3 (5), 2016a:141-155.

. “As Experiências da Diversidade Sexual e de Gênero em Quilombos do Nordeste e do Norte do Brasil: para Início de Conversa". Amazônica: Revista de Antropologia, 8 (1), 2016b: $62-$ 89.

GONTIJO, Fabiano; ERICK, Igor. "Experiências da Diversidade Sexual e de Gênero e Sociabilidades na Amazônia. ACENO: Revista de Antropologia do Centro-Oeste, 4 (7), 2017: 249-272.

“A Experiência da Diversidade Sexual e de Gênero no Pará: espaço público, representações e discursividades". Revista FSA, 13 (4), 2016: 40-59.

“Diversidade Sexual e de Gênero, Ruralidade, Interioridade e Etnicidade no Brasil: ausências, sileciamentos e... exortações". ACENO: Revista de Antropologia do Centro-Oeste, 2 (4), 2015:24-40.

GONTIJO, Fabiano; FERNANDES, Estêvão. "Sexualidade Amazônica”. In: ALBUQUERQUE, Gerson; SARRAF-PACHECO, Agenor (orgs.). Uwa'kürü - Dicionário Analítico - Volume 2. Rio Branco:Ed. NEPAN, 2017. pp.314-327.

GONTIJO, Fabiano; FERNANDES, Estêvão; TOTA, Martinho; LOPES, Moisés. Apresentação: Ainda sobre Novos Descentramentos e Outras Axialidades da Diversidade Sexual e de Gênero". Amazônica: Revista de Antropologia, 8 (2), 2016: 261-262.

GONTIJO, Fabiano: REIS, Pâmela L.; SOUSA, Rodrigo M. C. C.; COSTA, Francisca Célia S. "Discursividades Hegemônicas e Realidades Periféricas sobre Família, Amor, Gênero e Sexualidade ou... Quando o gênero se experimenta pelas margens". In: MOTTA, Diomar das Graças; SILVA, Raimunda Nonata (orgs.). Gênero em Debate: masculinidades nas relações de gênero no espaço escolar. São Luís: EdUFMA, 2017. pp. 43-63.

GONTIJO, Fabiano; SILVA, Daniel O. "A Arte Santeira no e do Piauí". Textos Escolhidos de Cultura e Arte Populares, 7 (1), 2010:51-64.

GONTIJO, Fabiano; SCHAAN, Denise P. Sexualidade e Teoria Queer: apontamentos para a Arqueologia e a Antropologia brasileiras. Revista de Arqueologia, v. 30, n. 2, p. 51-70. 2017. 
GONTIJO, Fabiano; SOUSA, Jaqueline P.; EVANGELISTA, Ianara S. “'Casar' ou 'Ficar'? 'Amar' ou 'Se Apaixonar'? Família e relacionamentos afetivos entre homossexuais de Teresina considerações sobre as relações entre gerações". In: BARROS Jr. (org.). Homossexualidades $e$ Gerações. Rio de Janeiro: Booklink, 2008. pp. 11-28.

GRAY, Mary L. Out in the Countryside: youth, media, and queer visibility in rural America. Nova York / Londres: New York Univesity Press, 2009.

GRAY, Mary L.; JOHNSON, Colin R.; GILLEY, Brian J. (orgs.). Queering the Countryside: new frontiers in rural queer studies. Nova York / Londres: New York Univesity Press, 2016.

JÓRIO, Amaury; ARAÚJO, Hiram da Costa. Escolas de Samba em Desfile: Vida, paixão e sorte. Rio de Janeiro: Poligráfica, 1969.

KOFES, Suely. Uma Trajetória em Narrativas. Campinas: Mercado das Letras, 2001.

LANDER, Edgardo (Org.). A Colonialidade do Saber. Buenos Aires: Clacso, 2005.

LEOPOLDI, José Sávio. Escolas de Samba, Rituale Sociedade. Petrópolis: Vozes, 1978.

MARCUS, George E. "Identidades Passadas, Presentes e Emergentes: requisitos para etnografias sobre a modernidade no final do século XX ao nível mundial". Revista de Antropologia, 34, 1991: 197-221.

McCLINTOCK, Anne. "Family Feuds: gender, nationalism and the Family". Feminist Review, 44, 1993: 61-80.

McGUIRE, Randall H. Archaeology as Political Action. Berkeley: University of California Press, 2008.

MENDES-LEITE, Rommel. "Genres e Orientations Sexuelles au Brésil: Une question d'apparences?" In : MENDES-LEITE, Rommel (org.). Homosexualités e Lesbianisme: Mythes, mémoires, historiographie. Lille: GKC,1993.pp.109-147.

MISKOLCI, Richard. "A Teoria Queer e a Sociologia: o desafio de uma analítica da normalização". Sociologias, 11 (21), 2009:150-182.

MITCHELL, Clyde. “The Situational Perspective". In: Cities, Society, and Social Perception: a Central African perspective. Oxford: Claredon Press, 1987. pp.1-33.

MOUTINHO, Laura. “Diferenças e Desigualdades Negociadas: raça, sexualidade e gênero em produções acadêmicas recentes". Cadernos Pagu, 42, 2014: 201-248.

ORTIZ, Renato. “Reflexões Sobre o Carnaval”. Ciência e Cultura, 28 (12), 1976: 1407-1412.

PARKER, Richard G. Corpos, Prazeres e Paixões: A cultura sexual no Brasil contemporâneo. São Paulo: Best Seller, 1991. 
PASSERON, Jean-Claude. "Biographies, Flux, Itinéraires, Trajectoires”. Revue Française de Sociologie, 31 (1), 1990:3-22.

PEIRANO, Mariza. Uma Antropologia no Plural. Brasília: EdUnB, 1992.

PENEFF, Jena. La Métode Biographique. Paris: Armand Collin, 1990.

PEREIRA DE QUEIROZ, Maria Isaura. Carnaval Brasileiro: O vivido e o mito. São Paulo: Brasiliense, 1992.

PISCITELLI Adriana. "Interseccionalidades, Categorias de Articulação e Experiências de Migrantes Brasileiras". Sociedade e Cultura, 11 (2), 2008: 263-274.

RIOS, Luís Felipe; ALMEIDA, Vagner de; PARKER, Richard; PIMENTA, Cristina; TERTO Jr., Veriano (orgs.). Homossexualidade: produção cultural, cidadania e saúde. Rio de Janeiro: ABIA, 2004.

RUBIN, Gayle. "The Traffic in Women: notes on the 'political economy' of sex". In: REITER, Rayna (org.). Toward an Anthropology of Women. Nova York: Monthly View Press, 1975. pp. 157210.

SÁ, Geysa E.; GONTIJO, Fabiano. “O Mercado Rosa de Teresina: identidades homossexuais, políticas públicas e economia”. In: GUIMARÃES, Simone de J.; BARROS Jr., Francisco de O.; GONTIJO, Fabiano; SILVA, Maria de Fátima do R.; PASSOS, Guiomar de O. (orgs.). Políticas Públicas em Tempos de Diversidades. Teresina: EdUFPI, 2006. pp.71-88.

SAMPAIO, Juciana. "Eu sou Aquilo que seus Olhos Veem": a vida de Janaína Dutra em meandros heteronormativos. Projeto de Pesquisa de Doutorado. Programa de Pós-Graduação em Ciências Sociais, Universidade Federal do Maranhão, 2011.

Do Glamour à Política: Janaína Dutra em meandros heteronormativos. Tese de Doutorado. Programa de Pós-Graduação em Ciências Sociais, Universidade Federal do Maranhã, 2015.

SCOTT, Joan. “Experience”. In: BUTLER, Judith; SCOTT, Joan W. (orgs.). Feminists Theorize the Political. Nova York / Londres: Routledge, 1992. pp. 22-40.

SILVA, Arnaldo Eugênio; GONTIJO, Fabiano. “A Bruxa Má de Teresina: um estudo do estigma sobre a Vila Irmã Dulce como um “lugar violento" (1998-2005)”. In: GUIMARÃES, Simone de J.; BARROS Jr., Francisco de O.; GONTIJO, Fabiano; SILVA, Maria de Fátima do R.; PASSOS, Guiomar de O. (orgs.). Políticas Públicas em Tempos de Diversidades. Teresina: EdUFPI, 2006. pp. 35-49.

SIMÕES, Júlio \& Sérgio CARRARA. “O Campo de Estudos Socioantropológico sobre Diversidade Sexual e de Gênero no Brasil: ensaio sobre sujeitos, temas e abordagens". Cadernos Pagu, 42, 2014:75-98.

STRATHERN, Marilyn. “Os Limites da Autoantropologia”. In: O Efeito Etnográfico. São Paulo: Cosac Naify, 2014. pp. 133-157. 
UZIEL, Anna Paula; GONTIJO, Fabiano. "Homossexualidades, Cultura e Identidade". In: GROSSI, Miriam P.; SCHWADE, Elisete (orgs.). Política e Cotidiano: estudos antropológicos sobre gênero, família e sexualidade. Blumenau: Nova Letra, 2006.

VALENÇA, Raquel T. Carnaval : Para tudo se acabar na quarta-feira. Rio de Janeiro: RelumeDumará, 1996.

VELHO, Gilberto. Desvio e Divergência: uma crítica da patologia social. Rio de Janeiro: Zahar, 1985.

WARNER, Michael. Fear of a Queer Planet: queer politics and social theory. Minneapolis/Londres: University of Minnesota Press, 1993. 